Biomass Support for the China Renewable Energy Law:

Feasibility Report-Agricultural and Forestry Solid Wastes Power Generation Demonstration

\section{December 2005}

Center of Renewable Energy Development Beijing, China

Energy Research Institute Beijing, China

National Development and Reform Commission Beijing, China
Subcontract Report NREL/SR-710-40627

October 2006 


\section{Biomass Support for the China Renewable Energy Law: Feasibility Report-Agricultural and Forestry Solid Wastes Power Generation Demonstration}

\section{December 2005}

Center of Renewable Energy Development

Beijing, China

Energy Research Institute

Beijing, China

National Development and Reform Commission

Beijing, China

NREL Technical Monitor: D. Lew

Prepared under Subcontract No. ACO-4-44015-01

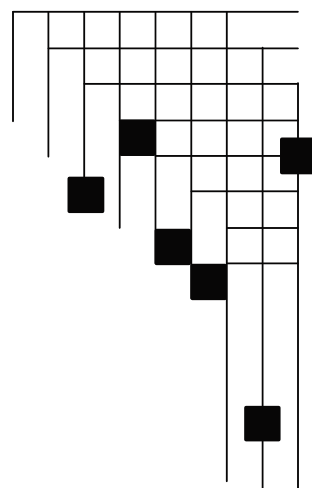




\section{NOTICE}

This report was prepared as an account of work sponsored by an agency of the United States government. Neither the United States government nor any agency thereof, nor any of their employees, makes any warranty, express or implied, or assumes any legal liability or responsibility for the accuracy, completeness, or usefulness of any information, apparatus, product, or process disclosed, or represents that its use would not infringe privately owned rights. Reference herein to any specific commercial product, process, or service by trade name, trademark, manufacturer, or otherwise does not necessarily constitute or imply its endorsement, recommendation, or favoring by the United States government or any agency thereof. The views and opinions of authors expressed herein do not necessarily state or reflect those of the United States government or any agency thereof.

Available electronically at http://www.osti.gov/bridge

Available for a processing fee to U.S. Department of Energy and its contractors, in paper, from:

U.S. Department of Energy

Office of Scientific and Technical Information

P.O. Box 62

Oak Ridge, TN 37831-0062

phone: 865.576 .8401

fax: 865.576 .5728

email: mailto:reports@adonis.osti.gov

Available for sale to the public, in paper, from:

U.S. Department of Commerce

National Technical Information Service

5285 Port Royal Road

Springfield, VA 22161

phone: 800.553 .6847

fax: 703.605.6900

email: orders@ntis.fedworld.gov

online ordering: http://www.ntis.gov/ordering.htm

This publication received minimal editorial review at NREL 


\section{CONTENTS}

1 Rudong Biomass Direct-fired Power Generation Project of Jiangsu .................................. 1

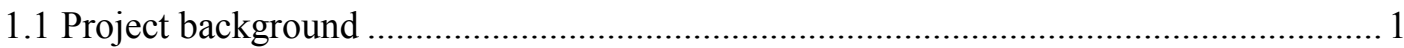

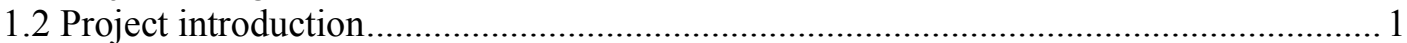

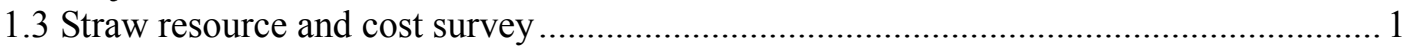

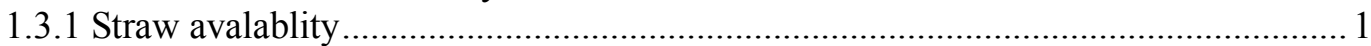

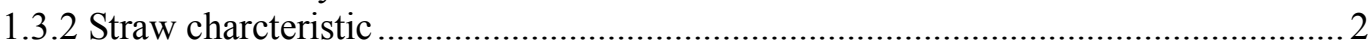

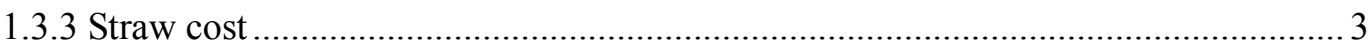

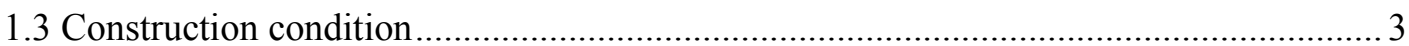

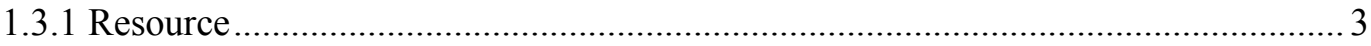

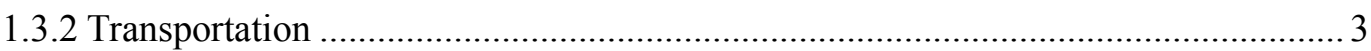

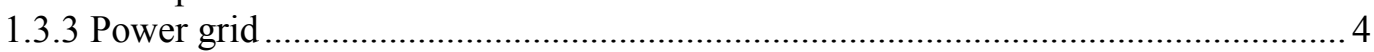

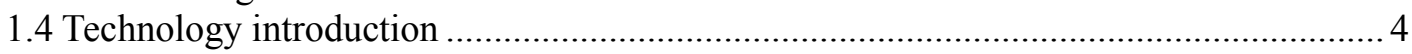

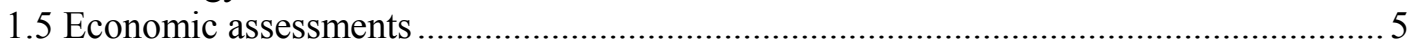

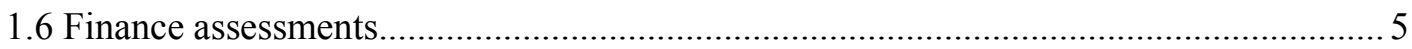

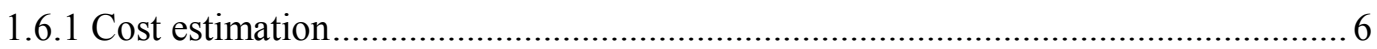

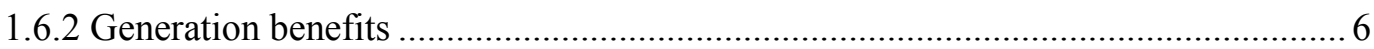

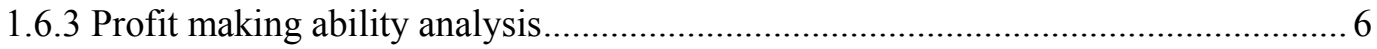

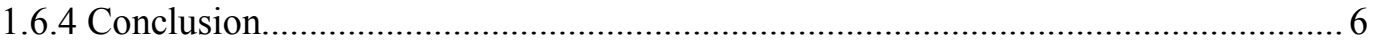

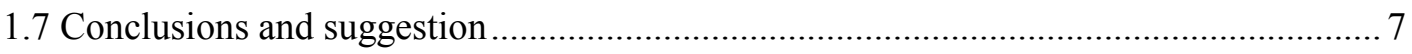

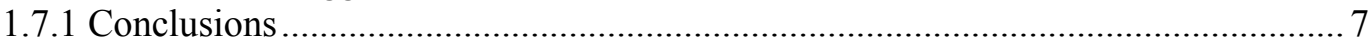

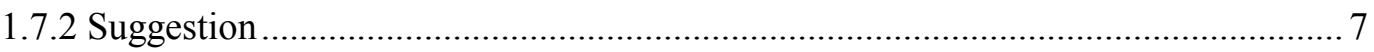

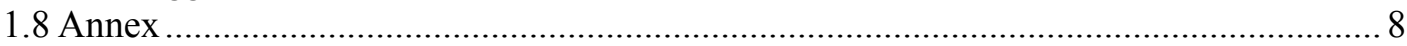

2 Gaoyou Biomass Fixed-bed Gasification power generation .................................................9

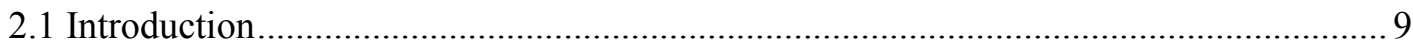

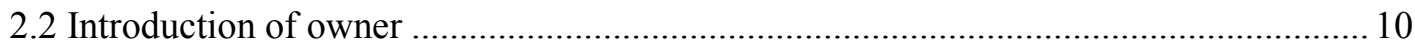

2.2.1 Basic information and assets of LinYuan Company .......................................... 10

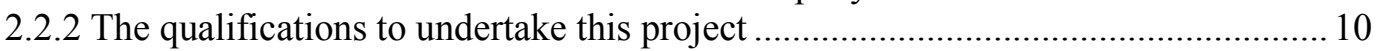

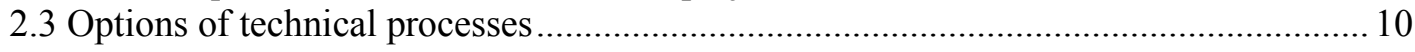

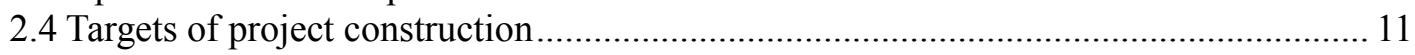

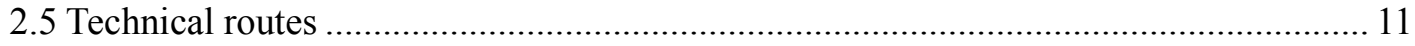

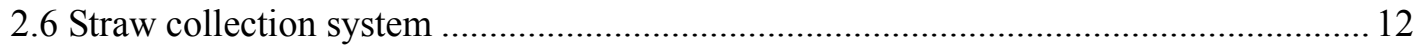

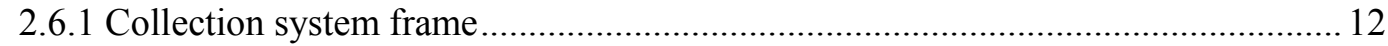

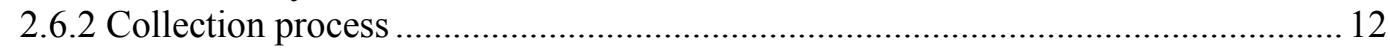

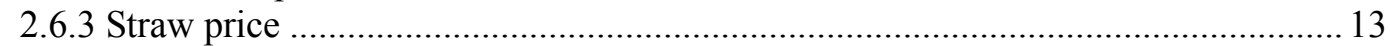

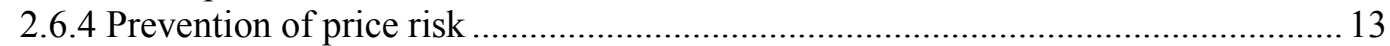

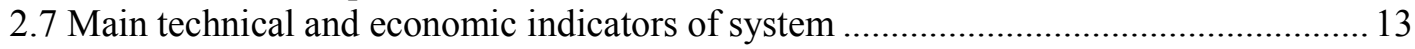

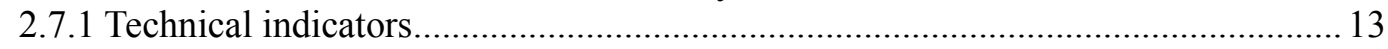

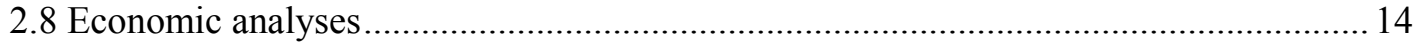

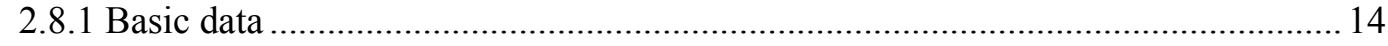

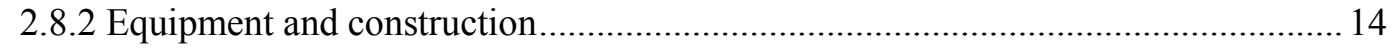

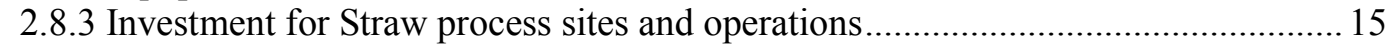

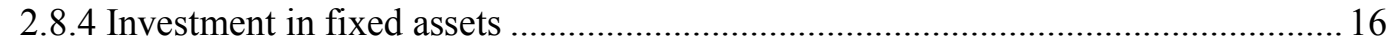

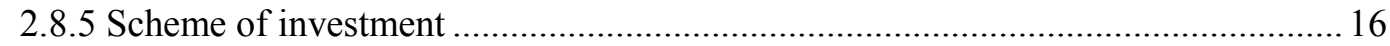

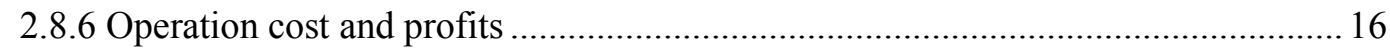

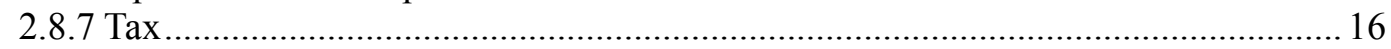

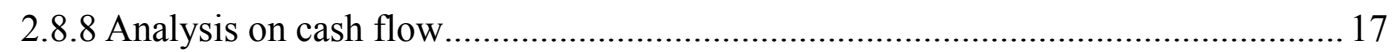

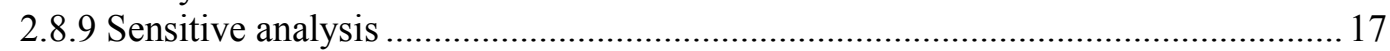

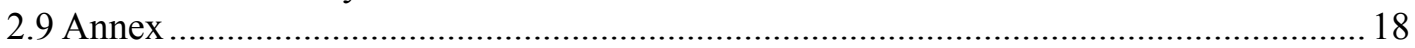


3 Xinhua biomass fliuldized bed gasification generation power.......................................... 19

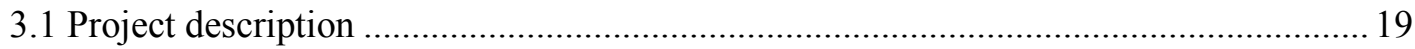

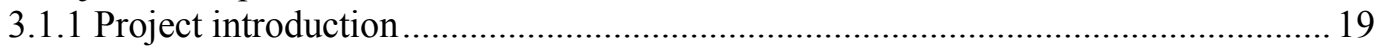

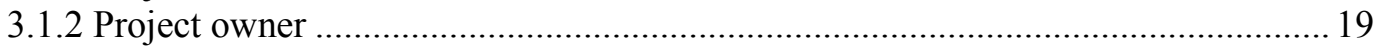

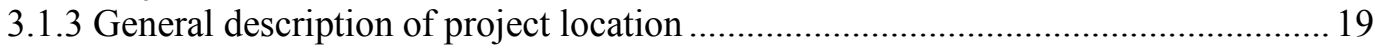

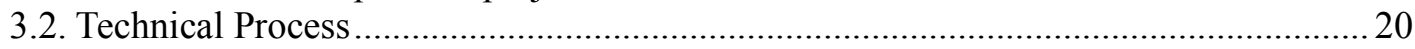

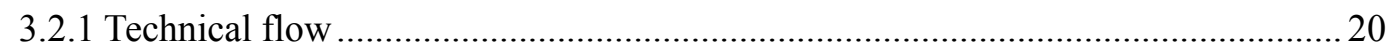

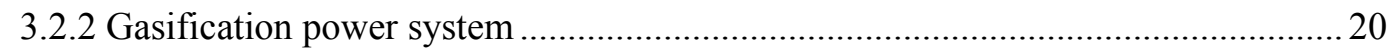

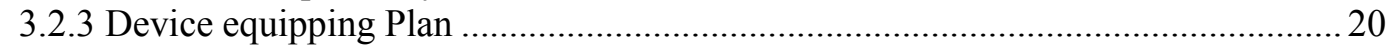

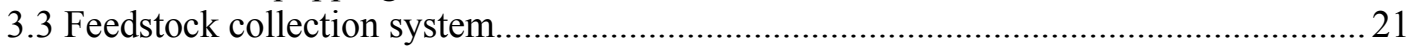

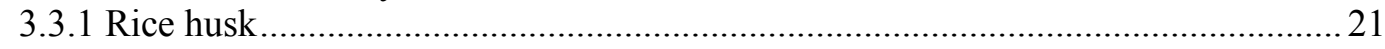

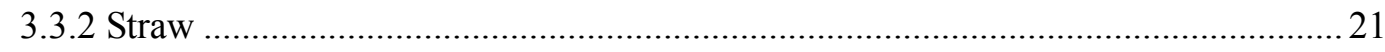

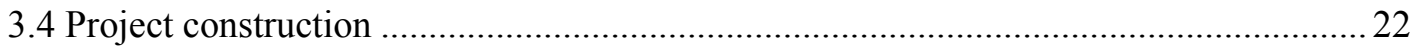

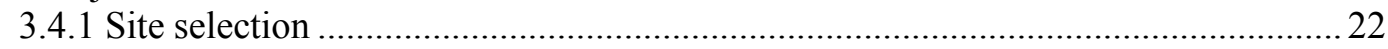

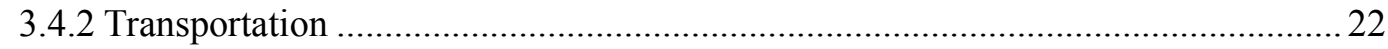

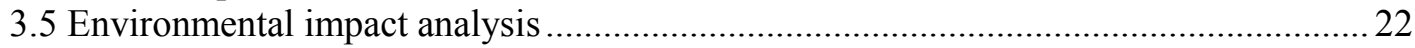

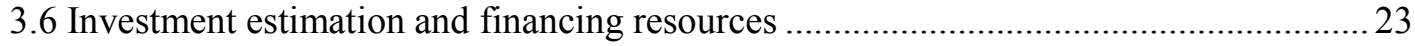

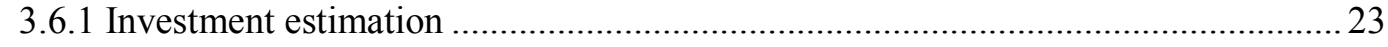

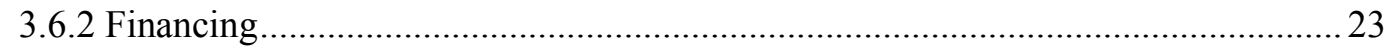

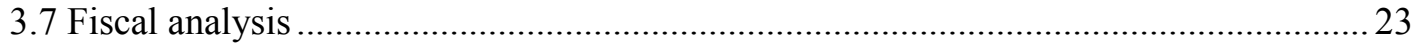

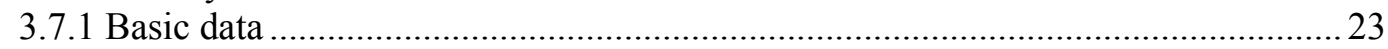

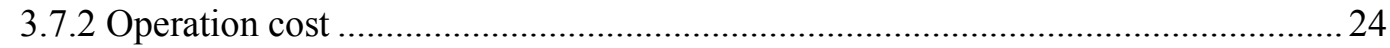

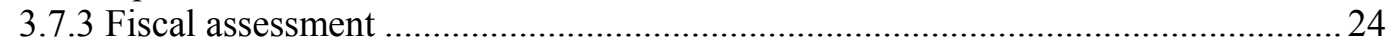

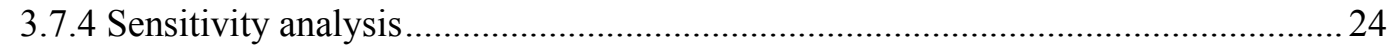

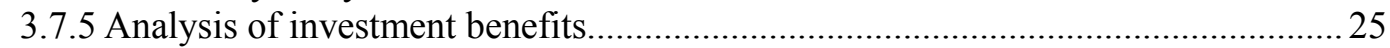

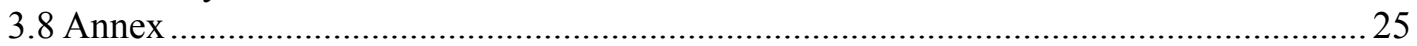




\section{Feasibility Research Report on the Agricultural and Forestry Solid Wastes Power Generation Demonstration Project}

\section{Rudong Biomass Direct-fired Power Generation Project of Jiangsu}

\subsection{Project background}

Rudong County of Jiangsu province locates in the Eastern China region along the eastern coastline, which is the downstream plain of Yangtze River. The total area of the county is $1873 \mathrm{~km}^{2}$, among which the arable land is around 1.58 million $M u$. The annual agriculture yield is over 900,000 Ton, with stalk productions of 790,000 ton. This area basically depends on agriculture. Meanwhile, the industries grow very fast. Rudong enjoys plenty of stalk resources, and its utilization will positively contribute to the energy consumption in Jiangsu province, which is significant to improve the economic and social development.

Currently, the stalk is basically used for cooking (roughly $30 \%-40 \%$ ), with direct combustion. The utilization efficiency is only $5-8 \%$. On the hand, there are substantial stalks that are burned directly inside the plowing field, which may influence the transportation, and even airport regulation. It wastes the precious energy resources, as well as seriously pollutes the environment. Stalk generation could not only address the fuel and electricity supply deficiency issue, but also replace the fossil fuel, so as to deploy the energy resources in a more reasonable approach.

\subsection{Project introduction}

Rudong stalk generation project is one of the important components of the new energy base construction in Rudong County. The total capacity is $24 \mathrm{MW}$, with electricity generation of $156 \mathrm{Gwh}$, $133 \mathrm{Gwh}$ of which is connected to the grid. In line with the National Renewable Energy utilization target, this project aims to import the oversea mature stalk generation technology and devices through international cooperation, so as to absorb and achieve the commercialization and scaling up of the stalk generation.

Rudong stalk generation project is located in the middle of Rudong project in Jiangsu province. It enjoys nice construction condition. This project could provide clean and reliable energy to the local economy development, and contribute to the local power grid. It could also replace the small steam coal-fired power plants whose development has been strictly controlled by the government, so as to reduce the coal consumption for power generation, which will be beneficial to the local environment and ecology protection. It is consistent with the government's sustainable energy strategy.

\subsection{Straw resource and cost survey}

\subsubsection{Straw availablity}

Through the spot survey of rural resident about 1000 household in Rudong, the output of straw for purchasing is about 7130 thousand tons (showns in Table1-3-1). Furthermore, the density of straw resource is high, and the production of straw is not effected on the climate. In $25 \mathrm{~km}$ radius, the output of straw for purchasing is about 7600 thousand tons, which can fully supply the project. 
Table 1-3-1 Straw resource output in Rudong (in $25 \mathrm{~km}$ radius)

\begin{tabular}{|c|c|c|c|c|c|c|}
\hline Type & $\begin{array}{c}\text { Planting } \\
\text { area } \\
(\mathbf{1 0 0 0 0} \mathbf{~ M u})\end{array}$ & $\begin{array}{c}\text { Total } \\
\text { output } \\
\text { (tons) }\end{array}$ & $\begin{array}{c}\text { Tatio of grain } \\
\text { to straw }\end{array}$ & $\begin{array}{c}\text { Output } \\
\text { (tons) }\end{array}$ & $\begin{array}{c}\text { Availability } \\
\text { rate } \\
\text { (\%) }\end{array}$ & $\begin{array}{c}\text { Availability } \\
\text { amount } \\
\text { (tons) }\end{array}$ \\
\hline Wheat & 48.26 & 140999 & $1: 1$ & 140999 & 25 & 35250 \\
\hline Barley & 35.19 & 91769 & $1: 1$ & 91769 & 27 & 24778 \\
\hline Bean & 22.79 & 45483 & $1: 1$ & 45483 & 21 & 9551 \\
\hline Rape & 23.96 & 37285 & $1: 1.6$ & 59656 & 23 & 13720 \\
\hline Rice & 84.86 & 501952 & $1: 0.623$ & 312716 & 45 & 237664 \\
\hline Corn & 15.63 & 63832 & $1: 1.5$ & 95748 & 68 & 65109 \\
\hline Tuber & 1.70 & 5634 & $1: 0.5$ & 2917 & & \\
\hline Peanut & 3.77 & 7771 & $1: 1.2$ & 11657 & & \\
\hline Cotton & 11.12 & 9929 & $1: 3$ & 29787 & 24 & 7149 \\
\hline Sesame & 0.18 & 431 & $1: 2$ & 862 & & \\
\hline Husang & 12 & & & 120000 & 100 & 120000 \\
\hline Bulrush & 20 & & & 200000 & 100 & 200000 \\
\hline Total & & 905085 & & 1111594 & & 713221 \\
\hline
\end{tabular}

Table 1-3-2 Sraw resources in the vicinity of Rudong (in $25 \mathrm{~km}$ radius)

\begin{tabular}{|c|c|c|c|c|}
\hline Item & Qian country & Shizong country & Shigang country & Total \\
\hline Planting area (Mu) & 69841 & 73325 & 85415 & \\
\hline Crop output (tons) & 39843 & 22909 & 53085 & \\
\hline Straw output (tons) & 43827 & 25200 & 58394 & 127421 \\
\hline Straw availability (tons) & 16873 & 9702 & 22482 & 49057 \\
\hline
\end{tabular}

\subsubsection{Straw charcteristic}

The four swatches, which are cotton, wheat, rice and rapeseed in six months, are delivered to test in Spain. Table1-3-3 lists the straw component and charcteristic.

Table 1-3-3 straw component and charcteristic

\begin{tabular}{|l|l|l|l|l|}
\hline Straw properties & Unit & Average fuel & Min. & Max. \\
\hline Moisture content & $\%$ & 11.0 & 7.0 & 25.0 \\
\hline Ultimate analysis (dry) & $\%$ & 18.7 & 16.5 & 21.5 \\
\hline - Fixed carbon & $\%$ & 76.1 & 71.9 & 80.9 \\
\hline -Volatiles & 5.2 & 2.6 & 11.5 \\
\hline Ash content (815C) & $\%$ & \multicolumn{1}{l|}{} \\
\hline Elementary analysis (dry) & \multicolumn{5}{l|}{} \\
\hline - Carbon & $\%$ & 45.4 & 41.5 & 47.8 \\
\hline -Hydrogen & $\%$ & 6.1 & 0.40 & 6.7 \\
\hline -Nitrogen & $\%$ & 0.60 & 0.05 & 0.96 \\
\hline -Sulfur & $\%$ & 0.08 & 36.77 & 43.36 \\
\hline -Oxygen & $\%$ & 41.16 & 0.07 & 1.19 \\
\hline -Chlorine [n] & $\%$ & 0.41 & 2.6 & 14.66 \\
\hline -Ash content (5.50C) & $\%$ & 6.26 & 15.60 & 17.60 \\
\hline LHV, dry & $\mathrm{MJ} / \mathrm{kg}$ & 17.04 & & \\
\hline LHV, as received & $\mathrm{MJ} / \mathrm{kg}$ & 14.97 & \\
\hline
\end{tabular}




\subsubsection{Straw cost}

The straw cost includes collecting, handling and transporting cost.

\subsubsection{Collecting cost}

Through the survey, the purchase price is about 84-196Yuan/tons, which is shown in Table1-3-4.

Table 1-3-4: straw purchase price

\begin{tabular}{|l|l|l|l|}
\hline Type & Availability (tons) & Share (\%) & $\begin{array}{c}\text { Purchase price } \\
\text { (Yuan/t) }\end{array}$ \\
\hline Wheat & 60028 & 15.3 & 104 \\
\hline Rice & 237664 & 60.4 & 96 \\
\hline Cotton & 7149 & 1.8 & 196 \\
\hline Corn & 65109 & 16.6 & 82 \\
\hline Bean & 9551 & 2.4 & 150 \\
\hline Rapeseed & 13720 & 3.5 & 84 \\
\hline
\end{tabular}

Based on Table1-3-4, the average price is 97.5 Yuan/t. If the straw is collected in large scale, the price of straw will increase. Furthermore, because the purchase amount is large, the project need set up about 10 collecting site, which will increase the collecting cost. Therefore, the collecting cost in practice is about 200Yuan/tons (the cotent of water is below $11 \%$ ).

\subsubsection{Handling cost}

The straw for the project need be handled by machine. The denisity of each bale is $1 \mathrm{t} / \mathrm{m} 3$ and the weight is $340-380 \mathrm{~kg}$. Based survey and evaluation, the handling cost is about $30 \mathrm{Yuan} / \mathrm{ton}$.

\subsubsection{Transporting cost}

In $15 \mathrm{~km}$, the transporting cost of straw is about 25 Yuan $/$ ton. Beyond $15 \mathrm{~km}$, the cost will reach 50 Yuan/tons.

In conclusion, the total cost of straw is 280 Yuan/ton

\subsection{Construction condition}

\subsubsection{Resource}

Rudong is within the JiangHai plain, and occupies abundant stalk resources. The arable land is 1.58 million Mu with 900,000 ton agricultural production. Taking into consideration of the mulberry and weed, the annual stalk production is accumulated to 1.11 million ton. Within $25 \mathrm{~km}$, the stalk production is 1.237 million ton, 0.76 million of which could be commercialized.

A sample survey within 1000 households in Rudong County indicated 713,000 ton of stalk could be commercialized given the price is within the scope of the farmers' anticipation. Since the stalk resource density is high, and seldom influenced by the climate, a commercial 760,000 ton can absolutely meet the requirements of this project when considering a $25 \mathrm{~km}$ collection radius and a high commercial awareness from the farmers.

\subsubsection{Transportation}

The dense roads and rivers note the Rudong County. The possession proportion of agriculture vehicles is quite high. Villages are connected by road. Groups are reachable by any vehicles. This means a sound condition for stalk transportation. There are three candidates location for this project, which is all 
within $1 \mathrm{~km}$ distance from the national road line 317 and fourth level canal. All of them could be reached directly by waterage or road carriage. This convenience could absolutely meet the requirements in terms of the devices or feedstock transportation.

\subsubsection{Power grid}

Rudong County power grid is the end of the JiangSu provincial power grid. The basic power plants are the nearby NanTong Power plant $(1.4 \mathrm{GW})$, TianShengGang plant $(550 \mathrm{MW})$. There are $2 * 220 \mathrm{KV}$, $6 * 110 \mathrm{KV}$ and $10 * 35 \mathrm{KV}$ substations. The power supply grid is based on the MaTang Substation of $220 \mathrm{KV}$, with the main $110 \mathrm{KV}$ substation and $110 \mathrm{KV}$ transmission lines, and supplemented by the $35 \mathrm{KV}$ substations and $35 \mathrm{KV}$ transmission lines. The three candidate sites are all close to the 220KV MaTang substation, and are quite easy to connect to the grid.

\subsection{Technology introduction}

The stalk resources come from the local farmers or the feedstock trader. In sequence with the collection, package, and transportation through rivers or vehicles to the factory storage, there comes to the following steps:

- Stalk transported from conveyor and shredder to the boiler

- Steam that produced from stalk combustion propels the steam turbines and generates electricity. The un-combusted stalk will stay at the bottom of the boiler. Meanwhile the ash enters the smoke filer chamber and emit through the chimney.

- The residues inside the boiler and the ash could be harnessed as the agricultural fertilizer.

A detailed technique flow can be as following:

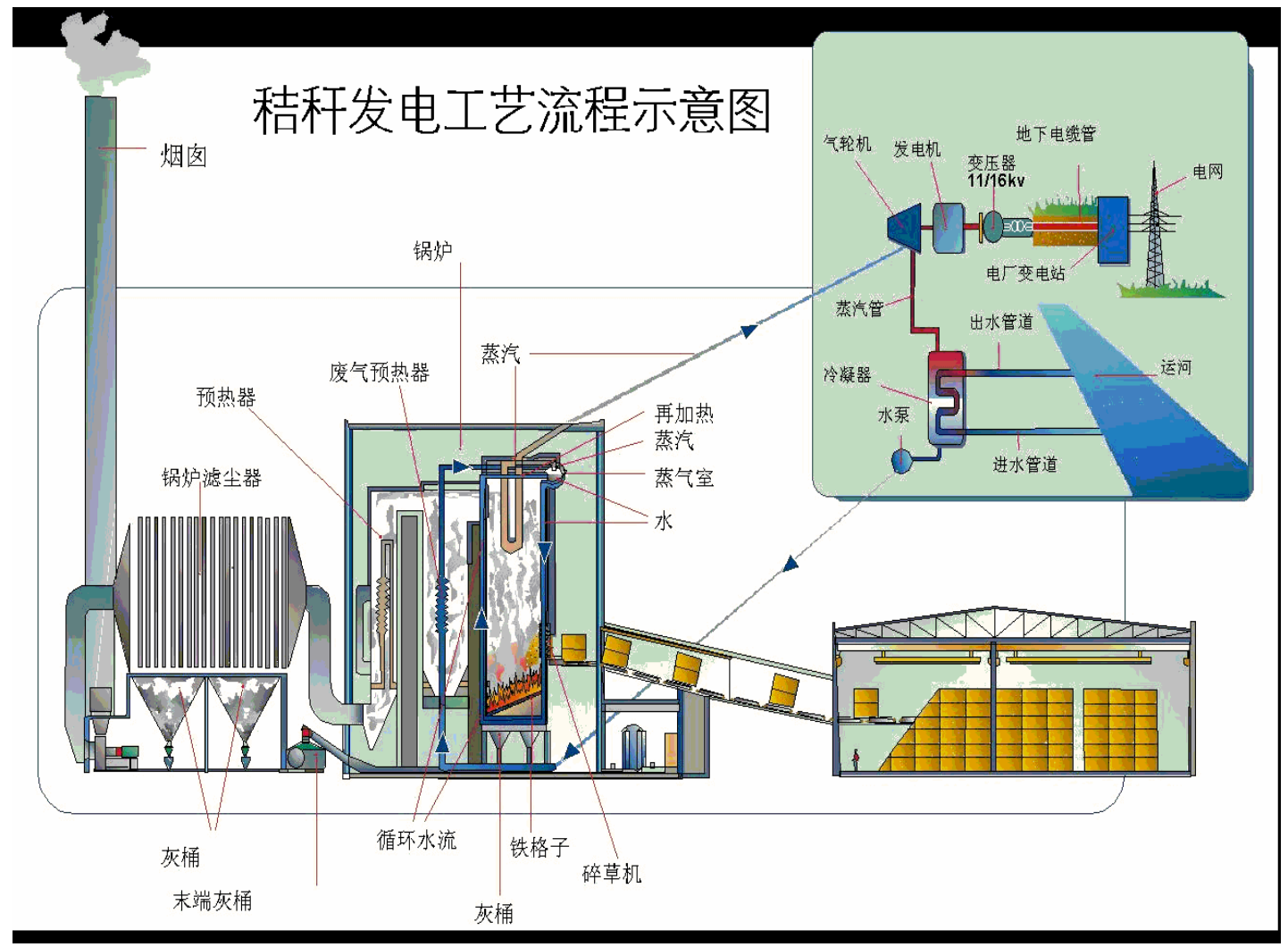




\subsection{Economic assessments}

This project is composed by the storage, boiler chamber, turbine etc. It occupies $101,000 \mathrm{~m}^{2}$. The gross investment is 333 million RMB. After two years construction period, the power capacity could reach $24 \mathrm{MW}$, and annually consumes stalk 140,000 ton. The annual operation hours is 6500 , and thus produces $156 \mathrm{GWh}$ and sale $132.6 \mathrm{GWh}$ to the grid. The annual sale value could reach 106 million RMB. Around 150 employments could be created.

The investment category is: $30 \%$ from capital cost, $67 \%$ from commercial bank loan, and another 20 million US\$ is needed to import the key devices.

- Total investment: 333.22 million RMB (inclusive of 20 million US\$)

- Unit investment (KW): $13885 \mathrm{RMB}$

- RMB currency exchange rate: $100 \mathrm{US} \$=826 \mathrm{RMB}$

The bank loan period started from 21th Feb 2004 with the interest rate of 5.76\%, and 15 years payback period. In addition to that, the flow capital during the first year was 15 million RMB, among which 5 million is self-capital, and 10 million comes from the flow capital bank loan.

- Power generation capacity: $24 \mathrm{MW}$;

- Annual electricity output: $156 \mathrm{GWh}$;

- On-grid electricity: $132.6 \mathrm{GWh}$;

- Construction period: 2 years

Table1-5-1 Fixed asset investment assessment (Unit: 10,000RMB)

\begin{tabular}{|l|l|c|}
\hline No. & Cost & Subtotal \\
\hline 1 & Fixed asset investment & 31992.80 \\
\hline 1.1 & Engineering cost & 27580 \\
\hline 1.1 .1 & Civil work and workshop construction $\left(10108 \mathrm{~m}^{2}\right)$ & 2525 \\
\hline 1.1 .2 & Production sector & 20582 \\
\hline 1.1 .2 .1 & Boiler (Denmark, FLS MIACJO) & 14382 \\
\hline 1.1 .2 .2 & Other devices & 6200 \\
\hline 1.1 .3 & Supplementary production sectors & 4214 \\
\hline 1.1 .4 & Other expense & 259 \\
\hline 1.2 & Contingency & 4412.80 \\
\hline 1.2 .1 & Basic contingency $(8 \%)$ & 2206.40 \\
\hline 1.2 .2 & Contingency for price ascend $(8 \%)$ & 2206.40 \\
\hline 2 & Regulation tax on fixed asset investment direction $(0 \%)$ & 0.00 \\
\hline 3 & Interest during construction & 1330.03 \\
\hline & Total investment: $1+2+3$ & 33322.83 \\
\hline
\end{tabular}

\subsection{Finance assessments}

Power generation capacity: 24MW; annual electricity output: $156 \mathrm{GWh}$; Ongrid electricity: 132.6 GWh; construction period: 2 years

The finance assessment work is as per the requirements of "Economy assessment approach and parameters for the construction project", which is jointly issued by the National Development and Planning Commission, and Ministry of Construction, and carried out in line with the current finance and 
tax policy as well as the current price systems. The calculation focused on cost and benefit, so as to explore its capability to make profit, payback ability etc finance condition, and further its finance feasibility.

The calculation period assumed 20 years, 2 construction years, and 18 operation years.

\subsubsection{Cost estimation}

The generation cost includes: depreciation, O\&M, salary and welfare, other cost and interest cost

The integrated depreciation rate: $6.67 \%$; O\&M rate: 1.0\%; Staff number: 150; average salary: $20,000 \mathrm{RMB} / \mathrm{a}$

The annual gross cost and operation cost is calculated to 78.86 million RMB (first year after operation) and 45.16 million RMB respectively.

\subsubsection{Generation benefits}

\subsubsection{Grid connection price}

The IRR is generally accepted as $12-15 \%$ by the similar foreigner project developer. Combined with the domestic situation, the IRR is taken as $12 \%$ for this project. Taking into account of the favorable policies for the grid-connected power plants, the grid-connected electricity price during operation period with and without VAT is $0.731 \mathrm{RMB} / \mathrm{kWh}$ and $0.806 \mathrm{RMB} / \mathrm{kWh}$ respectively.

\subsubsection{Sale revenue, tax and profit}

- Sale revenue

The grid-connected electricity: $132.6 \mathrm{kWh}$; grid-connected electricity tariff: $0.806 \mathrm{RMB} / \mathrm{kWh}$; sale revenue: 106.88 million RMB.

- Tax

The tax levied for the power projects include: VAT, sale surtax, income tax.

VAT: $17 \%$, exclusive of the price;

Sale surtax: inclusive of urban construction tax and education tax, $7 \%$ and $3 \%$ respectively; Income tax: $33 \%$

- Profit

Generation profit $=($ Generation income $)-($ generation cost $)-($ sale surtax $)$

After-tax profit $=$ (generation profit)-(income tax)

\subsubsection{Profit making ability analysis}

- The total FIRR (hereafter means after tax): $6.75 \%$

- Investment payback period: 10.26 years (ic $=6 \%$, excludes the construction).

- Average investment profit rate: $4.97 \%$

- Average investment tax rate: $10.94 \%$

- Capital cost IRR: $12 \%$, which means it is financially feasible.

\subsubsection{Conclusion}

The average grid-connected tariff during the operation period: Without VAT: $0.731 \mathrm{RMB} / \mathrm{kWh}$; Include VAT: $0.806 \mathrm{RMB} / \mathrm{kWh}$; Investment return period: 9.6 years; Capital cost IRR: 12\%; overall project IRR 6.75\%; higher than the coal-fired baseline IRR (6\%). Accordingly, it is financially viable. 


\subsection{Conclusions and suggestion}

\subsubsection{Conclusions}

\subsubsection{Necessity}

The RuDong 48MW stalk generation project is consistent with the $21^{\text {st }}$ sustainable energy strategy plan, which is a positive contribution to JiangShu energy consumption. Meanwhile, this region has the advantageous generation and resource condition. The social and environmental benefits are also evident. Therefore, it is desirable to explore the local stalk resources.

\subsubsection{Technology availability}

The 24MW stalk power plant has been successfully operated for 2 years in foreign countries. The combination of direct combustion technology and gasification technology has been quite mature. An environmental friendly biomass power plant with the most advanced technology in western country could consume 160,000 tons of stalks annually, and produce $200 \mathrm{GWh} / \mathrm{a}$. Its overall investment is 51 million Euros. The commercial operation proves to be very successful and technically viable.

The overall capacity is $24 \mathrm{MW}$, only $0.1 \%$ of the total capacity in JiangShu province. The electricity it produced could the power grid accept all.

There are no major disadvantageous geology problems that could bring negative influences to this project according to the geology materials.

The current road and transportation condition meet the requirements that the construction and feedstock transport need.

The local government is willing to offer positive support by providing the necessary land.

There are no negative factors that limit the project construction from the environment protection point of view. On the contrary, the project is beneficial for the environment.

\subsubsection{Evident social and environment benefits, desirable financial indicators}

Stalk is renewable resource. The RuDong power plant is positive contribution to JiangSu energy consumption as well as is environment friendly. It fills the blank in China in terms of the stalk utilization, which is significant for both the local economy development and improving the farmers' life quality. The project capacity during phase I is $24 \mathrm{MW}$, with total investment 33.322 million RMB. The unit investment is $13,885 \mathrm{RMB}$, which is substantially lower in comparison with the foreign biomass power plant with the similar scale. The local manufactured devices, except the imported boiler, conveyor systems etc, contributed to the lower cost. The financial analysis shows that the financial payoff ability is quite strong. The on-grid tariff is acceptable and financial indicator is reasonable.

\subsubsection{Suggestion}

With the high-speed development of the science and technology, the stalk power generation technology is becoming mature. Up to now, the foreign stalk generation is shifting from the pilot phase to the scale-up commercialization. As an emerging energy, government strong support is crucial to increase its competitively. In the worldwide, particularly in Germany, USA, Denmark, Spain etc, a series of favorable policies to promote the biomass resources utilization have been worked out, and has also achieved well effects.

JiangSu province is one of the developed provinces in China. There is a large energy demand. However, the primary energy resources are quite limited. It is necessary to make efforts to develop the 
provincial stalk resources to make up the primary energy deficiency, so as to satisfy the national economy development and improve the provincial environment. There is a need to formulate some favorable policies in line with JiangSu's condition to promote the stalk resources utilization and promote its commercial and scale-up development.

- There should be favorable policies in terms of the tax, land utilization for the stalk generation as high- and new-technology.

- Since the biomass raw material is generally collected from the farmers without any offset. However the present VAT has no definite regulation on this issue. It is recommended to provide $10 \%$ offset for buying the stalk from the farmers that is equivalent with the other agricultural productions.

- All of the produced electricity should be bought strictly as per "Renewable Energy Law". The stalk power plant does not need to regulate the peak load. The power transmission work, starting from the substation outlet of the power plant, to the designated substation for transmission and distribution, should be built by the utility.

- It is recommended to offer bank loan plan, preferential loan interest, innovation fund and other policy support etc.

\subsection{Annex}

- Annex 1-1:Investment plan and financing

- Annex 1-2:Operation cost and income

- Annex 1-3:Total cost

- Annex 1-4:Repay capital with interest of loan

- Annex 1-5: Profit and loss statement

- Annex 1-6: Cash flow (capital fund)

- Annex 1-7: Cash flow (total capital) 


\section{Gaoyou Biomass Fixed-bed Gasification power generation}

\subsection{Introduction}

Gaoyou city is located in an economic zone along the north of Yangtze River of Jiangsu province, and in the middle of Jiangsu province of Yangtze Delta and on the western fringe of Lixia River. Gaoyou city is neighbor with Xinghua city, connected with Jiangdu city, Hanjiang district and Yizheng city in the south, linked with Tianchang city (in Anhui province) and Jinhu county in the west, and bordered on Baoying county in the north. Total area of Gaoyou city is 1963 square kilometer, in which area of land covers 1175 square kilometer and water area 788 square kilometer. In 2004, there were 19 towns, 1 Hui nationality village (Xiang) and 1 provincial level economic development zone in Gaoyou city. The Basic information is shown in Table 2-1-1.

Table 2-1-1 Basic Information of Gaoyou city（in 2004）

\begin{tabular}{|c|c|c|}
\hline Items & Amount & Ranking* \\
\hline Population $\left(10^{4}\right)$ & 82.71 & 35 \\
\hline Local GDP $\left(10^{8}\right.$ RMB Yuan $)$ & 85.3 & 35 \\
\hline Value-added of the first industry $\left(10^{8}\right.$ RMB Yuan $)$ & 22 & 20 \\
\hline Value-added of the second industry $\left(10^{8}\right.$ RMB Yuan $)$ & 35 & 37 \\
\hline Value-added of industry $\left(10^{8}\right.$ RMB Yuan $)$ & 28 & 37 \\
\hline Value-added of the tertiary industry $\left(10^{8}\right.$ RMB Yuan $)$ & 28.3 & 32 \\
\hline Per capita local GDP (Yuan/person) & 10291 & 31 \\
\hline Total investment in fixed assets of urban $\left(10^{8} \mathrm{RMBYuan}\right)$ & 32.8 & 36 \\
\hline Total revenue $\left(10^{8}\right.$ RMB Yuan $)$ & 7.2 & 33 \\
\hline Per capital revenue (RMB Yuan) & 873 & 29 \\
\hline Yield of grain $\quad\left(10^{4}\right.$ tons $)$ & 58.5 & 14 \\
\hline Output of oil crops $\left(10^{4}\right.$ tons $)$ & 0.7 & 22 \\
\hline Output of meat $\left(10^{4}\right.$ tons $)$ & 5.3 & 49 \\
\hline $\begin{array}{l}\text { Total pre-tax profits of industrial enterprises with above } \\
\text { designated scale }\left(10^{8} \mathrm{RMB} \text { Yuan }\right)\end{array}$ & 4 & 35 \\
\hline Total retail sales of social consuming products ( $10^{8}$ RMB Yuan) & 24.3 & 31 \\
\hline Total amount of export $\left(10^{4} \mathrm{US} \$\right)$ & 9500 & 18 \\
\hline Actual direct investment from foreign merchant $\left(10^{4} \mathrm{US} \$\right)$ & 4072 & 35 \\
\hline Average wages of works and staffs at post (Yuan/year) & 11814 & 29 \\
\hline Per capita net income of rural residential (Yuan/year) & 4420 & 28 \\
\hline Per capital deposits of residential (Yuan/person) & 7296 & 24 \\
\hline
\end{tabular}

* It refers to Gaoyou city ranking within Jiangsu province.

Gaoyou city is located in the areas of Lixia River of Jiangsu province with a great quantity of straw resource. In 2004, yield of grain and oil crops was 585 thousand tons in Gaoyou city, and the amount of 
straw was 900 thousand tons. Because it has already applied harvester to gather in crops, the stalk of crops is left relatively high. The amount of straw available was about 450 thousand tons. If it considers that some of them were consumed by farmers themselves and some of them were crushed and returned to the farmland, the real amount of straw that can be used for power generation was about 300 thousand tons, among them stalk of wheat was 100 thousand tons, stalk of rice 170 thousand tons and stalk of rape (Brassica napus) 30 thousand tons. In addition, there are 100thousand mu reed growing at Gaoyou lakeside, so the stalk of reed can be also used for gasification power generation.

\subsection{Introduction of owner}

The owner of this project is LinYuan Science \& Technology Development Ltd. Company (LinYuan Company) of Gaoyou City.

\subsubsection{Basic information and assets of LinYuan Company}

LinYuan Science \& Technology Development Ltd. Company was established in 1991, and is an agricultural management entity integrated gain, forestry, fishery and seedling, and an agricultural comprehensive development and management ecological enterprise. LinYuan Company is located within Gaoyou city. It has $3000 \mathrm{mu}$ wood of poplar, $1000 \mathrm{mu}$ aquatic base, $500 \mathrm{mu}$ seedling base and $1000 \mathrm{mu}$ high quality and improved varieties of grain.

LinYuan Company is a shareholder enterprise with $25 \%$ shared by collective and $75 \%$ shared by private. Registered capital is 6 million RMB Yuan, and currently it has 46.5 million RMB Yuan of fixed assets (excluding the land). Total assets owned by LinYuan Company is 53 million RMB Yuan with zero liabilities. In 2004, it materialized over 3 million RMB Yuan of revenue.

\subsubsection{The qualifications to undertake this project}

LinYuan Science \& Technology Development Ltd. Company is always to dedicate itself to local agricultural comprehensive development, and to implement projects integrated agriculture, ecology and environment protection. In order to better use waste straw resources, LinYuan Company invested 1 million RMB Yuan in the test of straw briquetting and carbonization in 1995, and had a series of data available for purpose of development and mastered practical experience. However, due to technical and external reasons, it has a slow progress in this. China Renewable Energy Promotion Law has been issued in this year, and renewable energy technology has been developed greatly, all of which make LinYuan Company's envisagement about greatly utilization of straw become possible. Through a series of investigation and on-site survey, LinYuan Company decides to closely cooperate with enterprises that willingly do something in renewable energy industry and makes contributions to straw commercialization utilization in large scale.

\subsection{Options of technical processes}

According to the current status of straw power generation at home and abroad and real situation of Gaoyou city, it plans to select the technology of fixed bed countercurrent gasification. The reasons for this selection are:

In Gaoyou city, it takes a household as a unit to make agricultural production. Each household may provide about 30 thousand tons straw every year. If it adopts a technology of direct combustion power generation, the installed capacity of power plant will be $25 \mathrm{MW}$, and it will consume about 200 thousand tons of straw every year. If calculation based on 30 thousand tons straw provided by a household each year, it needs collect and purchase straw from 67 thousand rural households. In Gaoyou, the harvest of agriculture is two seasons per year, so it will try to complete the purchasing trade of 130 thousand straws collecting every year. This is really a huge workload for them, and causing quite high cost for straw collecting. And thus, it is obviously the direct combustion is not suitable for real situation of Gaoyou.

At present, boiler using for straw direct combustion power generation is often to consume one kind of raw fuel, whereas, one kind of biomass material cannot satisfy the needs by $25 \mathrm{MW}$ straw power plant. 
Therefore, it chooses technical process of straw gasification power generation that can consume various biomass materials.

\subsection{Targets of project construction}

The overall targets of project construction are:

- Total installed capacity of $4000 \mathrm{~kW}$; annual power generation of $26 \mathrm{GWh}$; power connected with grid of $22.88 \mathrm{GWh}$ annually.

- About 28-30 thousand tons of stalks of crops and forestry residue are consumed each year.

- The system of gas combustion purification and wastewater disposal facilities discharging satisfies the national standards.

- This project is run in a way of commercial business.

- The installed capacity of this project is $4000 \mathrm{~kW}$, and the period of construction is one year.

\subsection{Technical routes}

Through the analysis on existing technology of straw power generation at home and abroad, it will adopt fixed bed straw gasification power generation as technical process route for this project. The technical flow chart is shown as following:

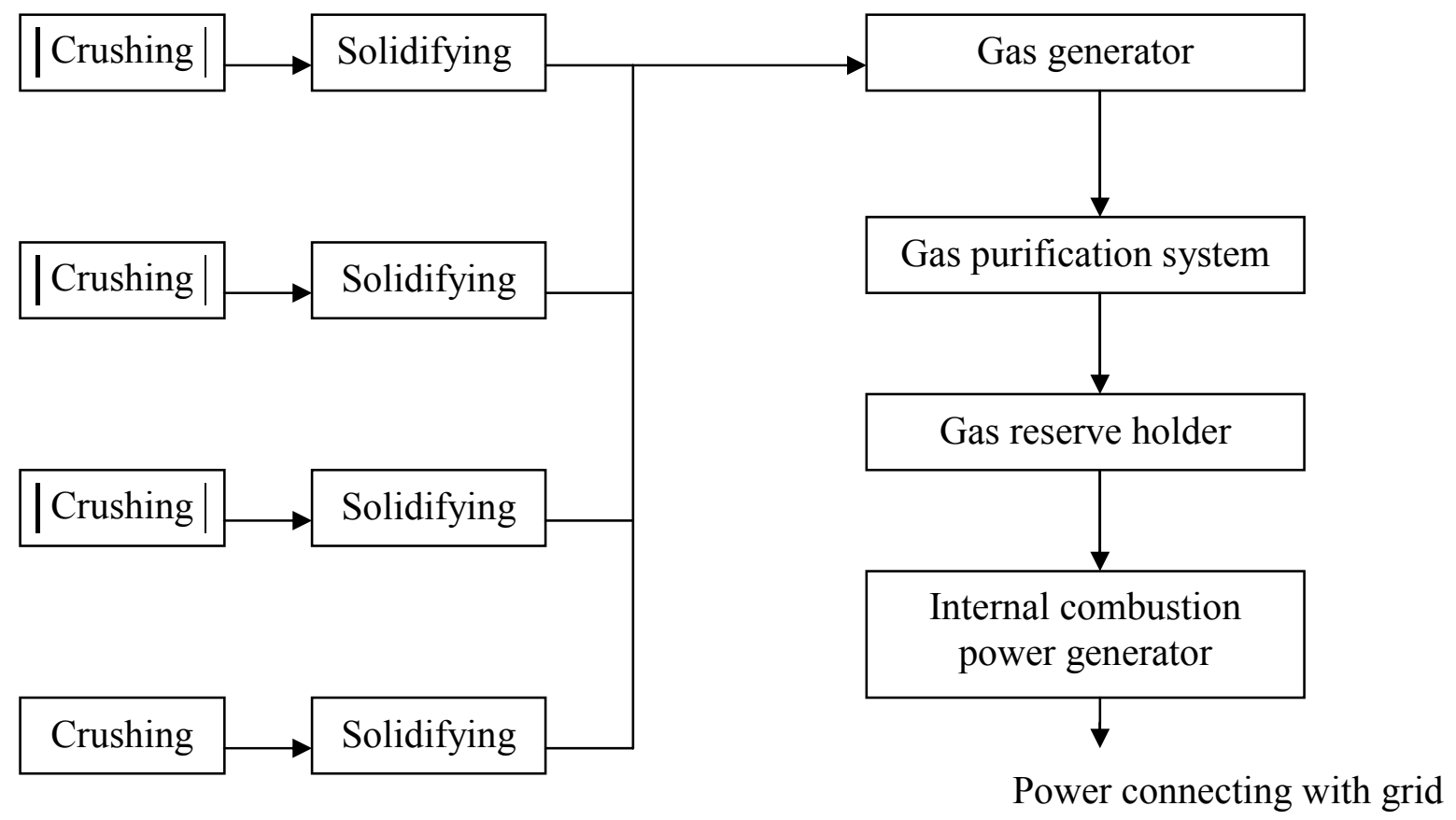

As shown in above-mentioned chart, the technical route used by this project is: after stalks of crops are crushed and briquetted, and then making it ready for raw materials that is needed for gasification. All of raw materials is collected and transported to straw gasification power generation plant. With gasification generator, the gas is generated. After gas is gong through a series of such processes as cooling, de-tarring and de-sulfuring, and then put purified gas into gas reserve holder; the clean gas is sent to internal combustion power generator for power generation.

The construction of this project consists of two systems: straw preparation system, including straw collecting, reserve, crush, briquette and transport; the other one is straw gasification power generation system, including straw gasification, gas purification, power generation and power transmission and distribution. 


\subsection{Straw collection system}

The operation of straw power plant depends on the supply straw to a great extent. Therefore, it is important to built straw collection system.

\subsubsection{Collection system frame}

The straw for generation power comes from 10 straw processing sites. (The economic analysis of these sites is shown in the tenth part of this report). Each site has 30-40 agents for straw collection, and then each agent purchase the straw form 100 household rural residents (shown as Figure)

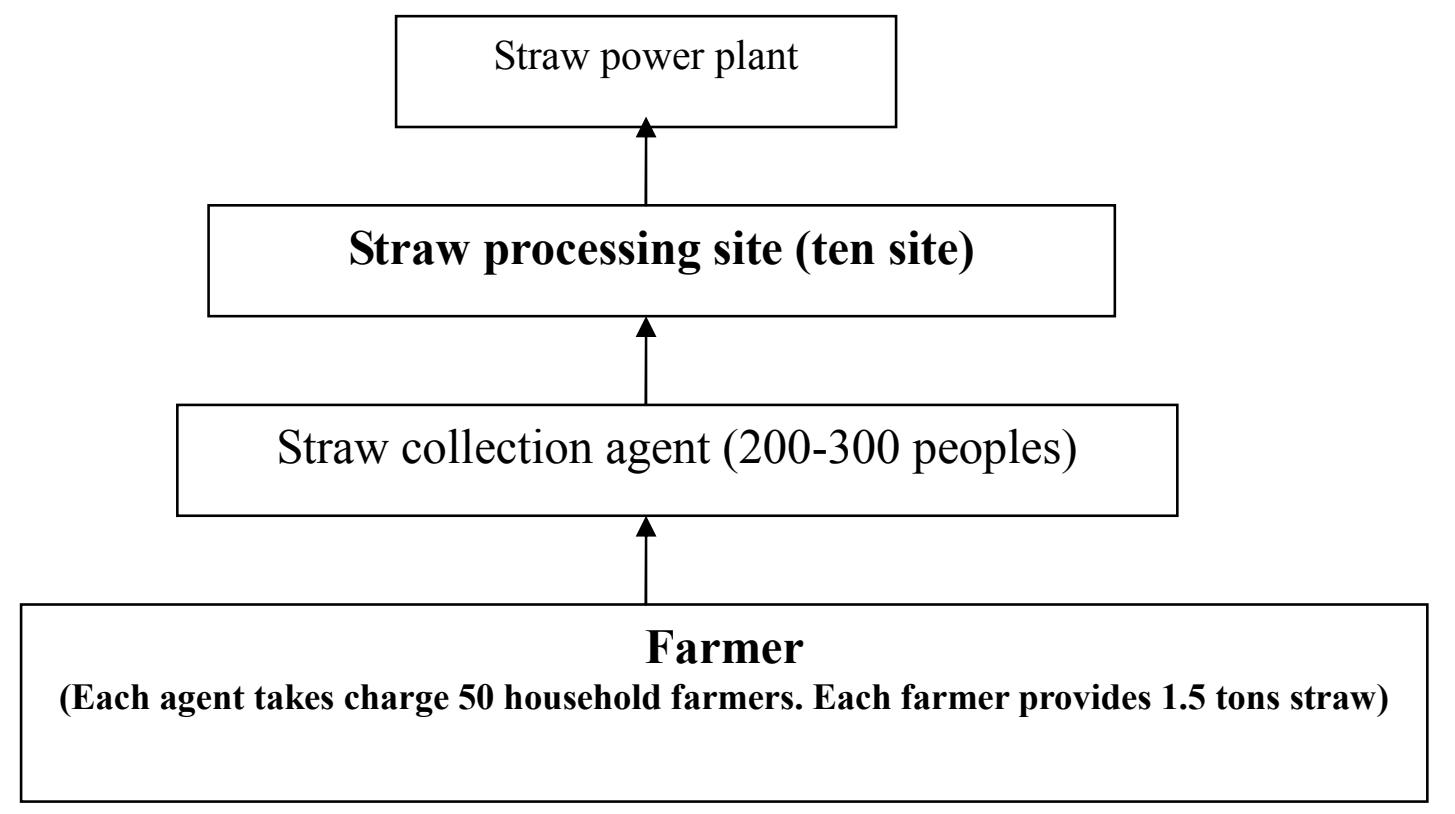

\subsubsection{Collection process}

\subsubsection{Straw processing site}

The straw power plant will establish 10 straw processing sites in certain radius. The distance between these sites from the power plant is about 5-10 kilometer. Furthermore, the distance between two sties is about 5 kilometer. The main assignment of these sites includes:

- Collect and storage straw

- Smash and solidify straw

- Transport straw according to the arrangement of the biomass power plant

The production of each straw processing site is 4000 tons every year. Each site has tow straw solidifying machines, and the matching equipment, such as smash, drying and transportation.

Each straw process site manages 30-40 agent of straw collection. These agents will collect straw from the farmer to directly deliver to the straw process sites and contracts with each farmer to confirm the number, quantity and price of straw.

\subsubsection{Agent of straw collection}

The agent of straw collection is the key of relation between farmers and straw process site, therefore, which is main the peasant in the local area of the site. In the light of the scale of village, each village will select 3-4 agents and each agent will be charged with 50 household farmers. 


\subsubsection{Farmer}

In the collection system of this project, the main task of farmer is only agreeing with the straw bargain according to the acceptable price. The farmers need not consider the transportation and drying of straw.

\subsubsection{Straw price}

For correctly confirming the straw price, the investor test for the straw purchase in the summer in 2005. The result is shown in Table2-6-1

Table 2-6-1 Straw collection cost

\begin{tabular}{|l|l|l|}
\hline \multicolumn{1}{|c|}{ Item } & \multicolumn{1}{|c|}{ Cost (Yuan/tons) } & \multicolumn{1}{c|}{ Note } \\
\hline Purchase cost & 50 & Exclude collection, drying and delivering \\
\hline Collection worker salary & 50 & $\begin{array}{l}\text { The worker is charged with collecting the } \\
\text { straw in the cultivated field }\end{array}$ \\
\hline $\begin{array}{l}\text { Worker salary for raw } \\
\text { straw transportation }\end{array}$ & 20 & $\begin{array}{l}\text { The transportation distance is between the } \\
\text { cultivated field and the straw drying site }\end{array}$ \\
\hline Keeper salary & 30 & $\begin{array}{l}\text { The keeper is charged with incepting, drying, } \\
\text { stacking and keeping straw in the straw } \\
\text { drying site }\end{array}$ \\
\hline $\begin{array}{l}\text { Dry straw transportation } \\
\text { cost }\end{array}$ & 10 & $\begin{array}{l}\text { The transportation distance is between the } \\
\text { straw drying site and the straw processing site }\end{array}$ \\
\hline Total & 160 & \\
\hline
\end{tabular}

The table shows the total cost form the cultivated filed to the processing site is about 160 Yuna/tons. If the site purchases the straw in the light of 190 Yuan/tons price, the profit of agent will be 30 Yuan/tons.

\subsubsection{Prevention of price risk}

With straw power plant operating, the straw consumption will increase, which can induce the straw price increasing to some degree.

For preventing the risk of straw price increasing, the two measures will be adopted.

- Enlarge straw collection radius. In the range covered by the straw collection system, the straw supply should exceed the straw demand.

- Increase straw purchase price of processing site. Because the worker salary is decided by the manpower resource in the local, the salary will not increase with straw power plant operating. Therefore, the uncertain factor of straw price increasing is the purchase price for raw straw, which can be confirmed 70-80 Yuan/tons to remain the room for price increasing.

\subsection{Main technical and economic indicators of system}

\subsubsection{Technical indicators}

- Straw use

- Capacity of maximum gas generated

- Heat value of gas

- Capacity of generator

- Annul power generation

- Annual power grid connection

$28535 \mathrm{t} /$ year

$10000 \mathrm{~m}^{3} / \mathrm{h}$

$1350 \mathrm{kcal} / \mathrm{m}^{3}$

$4000 \mathrm{~kW}$

$26 \mathrm{MWh}$

$22.88 \mathrm{MWh}$

- Area covering (gasification power station) $10000 \mathrm{~m} 2$

- Rate of gas generated by straw

- Straw use by unit power generation

- Gas tar content
$1.86 \mathrm{~m}^{3} / \mathrm{kg}$

$1.098 \mathrm{~kg} / \mathrm{kwh}$ 
- Gas sulfur content

- Life-span

\subsection{Economic indicators}

- Total investment

In which: interest during construction

- Investment in fixed assets

In which: Straw power plant

Site for straw processing

Research \& experiment

- Amount of sites for straw processing

- Annual net revenue from each straw processing site

- Annual net revenue of straw power plant (before tax)

- Annual net revenue of straw power plant (after tax)

- IRR (before tax)

- IRR (after tax)

- Investment payback period (before tax)

- Investment payback period (after tax)

- Self-owned capital IRR (after tax)

- Self-owned capital NPV (after tax)

- Self-owned capital investment payback period (after tax) 10.11 year
33.826 Million Yuan

682 Thousand Yuan

33.14 Million Yuan

28.48 Million Yuan

4.66 Million Yuan

1.87 Million Yuan

10

\subsection{Economic analyses}

We adopt the method described in "Economic Analysis of Feasible Study for Construction Project" issued by the National Development and Reform Commission to make our economic analysis

\subsubsection{Basic data}

- Scale of project (Installed capacity)

- Amount of site for straw processing

- Construction period

- Share of self-owned capital

- Annual interest rate

$$
\begin{aligned}
& 4000 \mathrm{~kW} \\
& 10 \\
& \quad 12 \text { months } \\
& 30 \% \text { } 5.76 \%
\end{aligned}
$$

\subsubsection{Equipment and construction}

Main equipment of straw power generation plant includes systems of gasification, gas purification, power generation, power transforming $\&$ transmission and auxiliary. The detail information is shown in Table 2-8-1.

Table2-8-1 Main equipment of straw gasification station

\begin{tabular}{|c|l|c|c|c|}
\hline No. & Equipment & Amount & Unit price & Total price \\
\hline 1 & Machines for straw crushing and briquette & 20 & 23.3 & 466 \\
\hline 2 & Gasification system & 1 & 400.5 & 400.5 \\
\hline 3 & Gas purification system & 1 & 195 & 195 \\
\hline 4 & Power generation system & 1 & 1041.5 & 1041.5 \\
\hline 5 & Power transforming \& transmission & 1 & 120 & 120 \\
\hline 6 & Auxiliary system & 1 & 40 & 40 \\
\hline 7 & Total & 1 & 2263 & 2263 \\
\hline
\end{tabular}

Construction of power plant mainly consists of gasification workshop, power generation work and raw materials storehouse. Total area covers $1870 \mathrm{~m} 2$ with building cost of $1014 \mathrm{Yuan} / \mathrm{m}^{2}$. Main buildings are listed in Table2- 8-2. 
Table2-8-2 List of buildings

\begin{tabular}{|l|c|c|c|}
\hline \multicolumn{1}{|c|}{ Buildings } & Area $\left(\mathbf{M}^{\mathbf{2}}\right)$ & Unit cost $\left(\mathbf{Y u a n} / \mathbf{M}^{\mathbf{2}}\right)$ & Total cost $\left(\mathbf{1 0}^{\mathbf{4}}\right.$ Yuan) \\
\hline Gasification workshop & 800 & 1200 & 96 \\
\hline Power generation workshop & 150 & 1200 & 18 \\
\hline Pump-house & 20 & 800 & 1.6 \\
\hline Recycled water pool & 100 & 600 & 6 \\
\hline Waste water disposal pool & 50 & 600 & 5 \\
\hline Main controlling room & 50 & 1000 & 24 \\
\hline Raw material storehouse & 400 & 600 & 36 \\
\hline Offices (Lab) & 300 & 1200 & $\mathbf{1 8 9 . 6}$ \\
\hline Total & $\mathbf{1 8 7 0}$ & $\mathbf{1 0 1 3 . 9}$ & \\
\hline
\end{tabular}

\subsubsection{Investment for Straw process sites and operations}

It plans to set up 10 sites for straw processing. The power plant will provide 2 straw briquette machines and 2 crushing machines for each site, with annual production of 3000 tons briquette straw. For straw processing sites, it mainly has crushing machine, briquette machine and tractor. Among them, the crushing machine and briquette machine will be provided by straw power plant, so it only needs the processing site to prepare transporting vehicles by themselves. The investment for this is about 25 thousand Yuan.

The operation cost of straw processing site mainly refers to the costs of salary, electricity, raw materials and product transport. The power plant will purchase processed briquette products at a price of 300 Yuan per ton with net profits of 28600 Yuan. The detailed analysis please sees Table2-8-3.

Table 2-8-3 Investment and operation cost of processing site

\begin{tabular}{|c|c|c|c|c|c|}
\hline No. & Items & Unit & Annual us & nit pri & nvestment \\
\hline 1 & Input & & & & 541400 \\
\hline 1.1 & Maintenance & Yuan/yr. & & & 10000 \\
\hline 1.2 & Salary & Person.month/yr. & 48 & 800 & 38400 \\
\hline 1.3 & Electricity fee & Yuan/kWh & 120000 & 0.75 & 90000 \\
\hline 1.4 & Total cost of raw materials & & & & 384000 \\
\hline 1.4 .1 & Cost of raw material purchasing & Yuan/ton & 2000 & 190 & 380000 \\
\hline 1.4 .2 & Rent for site & & 2000 & 2 & 4000 \\
\hline 1.5 & Cost of product transport & Yuan/ton & 1900 & 10 & 19000 \\
\hline 2 & Output & & & & 570000 \\
\hline 2.1 & Sales of briquette straw & Yuan/ton & 1900 & 300 & 570000 \\
\hline 3 & Tax & & & & $\mathbf{0}$ \\
\hline 3.1 & Business tax & & & $0 \%$ & 0 \\
\hline 3.2 & Construction fund & & & $7 \%$ & 0 \\
\hline 3.3 & Education surcharge & & & $3 \%$ & 0 \\
\hline 4 & Net profits & & & & 28600 \\
\hline
\end{tabular}




\subsubsection{Investment in fixed assets}

Total investment of this project is 33.83 million Yuan, among them investment of fixed assets is 33.14 million Yuan, and interest during the construction is 682 thousand Yuan, research \& experiment is 1.87 million Yuan. The crushing machine and briquette machine are provided by power plan with total investment of 4.66 million Yuan. The transport vehicles will provide by raw materials processing site itself. Investment of fixed assets is detailed in Attached Table 1.

\subsubsection{Scheme of investment}

Total investment of this project is 33.83 million Yuan, in which self-owned capital accounts for $30 \%$ with 10.15 million Yuan, and loan from commercial bank accounted for $70 \%$ with 23.68 million Yuan. The rate of bank interest is based on $5.67 \%$ annually. The detailed scheme of investment is shown in Table2-8-4.

Table 2-8-4 Scheme of investment

\begin{tabular}{|c|c|c|c|c|}
\hline \multirow{2}{*}{ No. } & \multirow{2}{*}{ Item } & Construction & period & \multirow{2}{*}{ Total } \\
\hline & & 1 & & \\
\hline 1 & Total investment & & 3382.61 & 3382.61 \\
\hline 1.1 & Investment of fixed assets & & 3314.41 & 3314.41 \\
\hline 1.2 & Regulating tax of fixed assets investment & & & 0.00 \\
\hline 1.3 & Interest during construction & & 68.19 & 68.19 \\
\hline 1.4 & Operating fund & & & 0.00 \\
\hline 2 & Capital channeling itself & & 3382.61 & 3382.61 \\
\hline \multirow[t]{2}{*}{2.1} & Itself-owned capital & & 1014.78 & 1014.78 \\
\hline & In which: used for operating fund & & & 0.00 \\
\hline 2.2 & Loan & & 2367.83 & 2367.83 \\
\hline 2.2 .1 & Long-term loan & & 2367.83 & 2367.83 \\
\hline 2.2 .2 & Loan for operating fund & & & 0.00 \\
\hline 2.2 .3 & Other short-term loan & & & \\
\hline 2.3 & Others & & & \\
\hline
\end{tabular}

\subsubsection{Operation cost and profits}

\subsubsection{Operation cost}

Annual operation cost is 10.68 million Yuan. The operation cost and total cost is detailed in Attached Table 2 and Attached Table 3.

\subsubsection{Profits}

For this project, $22.88 \mathrm{MWh}$ will be put on power grid. If the price of electricity sold to power grid is 0.727 Yuan/kWh, an annual net profit is 5.36 million Yuan (before tax) and 3.58 million Yuan (after tax).

\subsubsection{Tax}

This project mainly consists of value-added tax, sale tax surcharge and income tax. The sale tax 
surcharge includes city construction fund and education surcharge with rate of $5 \%$ and $3 \%$ of value-added tax. Rate of income tax is $33 \%$. In this report, it does not consider any preferential for taxation.

\subsubsection{Analysis on cash flow}

Based on above-mentioned data, if the project is 15 years life-span (excluding construction period), the resulted current flow is as following:

- IRR: $10.85 \%$ (before tax), $7.59 \%$ (after tax)

- NPV (basic profit rate of 6\%): 11.66 million Yuan (before tax), 3.58 million Yuan (after tax)

- Investment payback period: 7.59 years (before tax), 9.04 years (after tax)

- Self-owned capital IRR: $12.02 \%$ (after tax)

- Self-owned capital NPV: 6.47 million Yuan

- Self-owned capital investment payback period: 10.11years

The detailed cash flow analysis is shown in Attached Table 4-5.

\subsubsection{Sensitive analysis}

It carries out the sensitive analysis on main influent factors of straw gasification power generation project. The basic method is to increase and decrease $10 \%$ of each influent factor, and then it calculates IRR before income tax of this project. It takes the following influent factors to analyze project sensitive:

- Investment

- Price of electricity that put on power grid

- Price of raw material purchasing

- Rate of interest of loan

Data in Table 9-5 shows that price of electricity is a major factor to influence the profits of project with degree of sensitive of 5.12. For this regard, the rational electricity price is a key element to let this project obtain profits. Under the guarantee of renewable energy law, the generated power will be totally purchased, which can be brought about relatively good economic benefits. At time of this project is established, "China Renewable Energy Law" would have been put into effects. So it can get beneficial from "China Renewable Energy Promotion Law", in which it stipulates that it should purchase total renewable generation with fixed electricity price. Therefore, it can great improve its capacity to combat the risk of project. 
Table 2-8-5 Sensitive analysis of straw gasification power generation

\begin{tabular}{|c|c|c|c|c|c|}
\hline Influent factor & Value & $\begin{array}{c}\text { Rate of } \\
\text { changing }\end{array}$ & IRR $(\%)$ & $\begin{array}{c}\text { Rate of IRR } \\
\text { changing }\end{array}$ & $\begin{array}{c}\text { Co-efficiency of } \\
\text { sensitive }\end{array}$ \\
\hline \multirow{2}{*}{$\begin{array}{l}\text { Production load } \\
\text { (6500 hours/yr.) }\end{array}$} & 7150.0 & $10 \%$ & 15.64 & $30.12 \%$ & \multirow[b]{2}{*}{2.48} \\
\hline & 5850.0 & $-10 \%$ & 9.69 & $-19.38 \%$ & \\
\hline \multirow{2}{*}{$\begin{array}{c}\text { Fixed assets } \\
\text { (33.144 M Yuan) }\end{array}$} & 3645.9 & $10 \%$ & 9.83 & $-18.22 \%$ & \multirow[b]{2}{*}{2.65} \\
\hline & 2983.0 & $-10 \%$ & 16.2 & $34.78 \%$ & \\
\hline \multirow{2}{*}{$\begin{array}{l}\text { Electricity price } \\
(0.727 \mathrm{Yuan} / \mathrm{kWh})\end{array}$} & 0.800 & $10 \%$ & 18.73 & $55.82 \%$ & \multirow[b]{2}{*}{5.12} \\
\hline & 0.654 & $-10 \%$ & 6.42 & $-46.59 \%$ & \\
\hline \multirow{2}{*}{$\begin{array}{c}\text { Rate of loan interest } \\
0.576 \%\end{array}$} & $0.634 \%$ & $10 \%$ & 12.02 & $0.00 \%$ & \multirow[b]{2}{*}{0.17} \\
\hline & $0.518 \%$ & $-10 \%$ & 12.43 & $3.41 \%$ & \\
\hline
\end{tabular}

\subsection{Annex}

- Annex 2-1: Investment

- Annex 2-2:Operation coat and income

- Annex 2-3: Total cost

- Annex 2-4:Cash Flow (Total capital)

- Annex2-5: Cash Flow (Capital Fund) 


\section{Xinhua biomass fliuldized bed gasification generation power}

\subsection{Project description}

\subsubsection{Project introduction}

To construct a $4000 \mathrm{~kW}$ biomass power plant using the rice hull from rice milling plant in Daiyao Town, Xinghua City, Jiangsu Province. The power plant will be equipped with a $2500 \mathrm{~kW}$ internal combustion generator unit and a $1500 \mathrm{~kW}$ steam turbine generator unit.

\subsubsection{Project owner}

The project owner is the Xinghua Suyuan Biomass Power Generation Co. Ltd jointly set up by Zhenjiang Zhongke Huadian New Energy Co. Ltd and Daiyao Town of Xinhua City, Zhejiang Province.

\subsubsection{General description of project location}

Xinghua city is located at the economic belt of Yangtze River Delta, and in the influx center of Taizhou, Yangzhou, Tantong, Yancheng economic zone, Jiangsu Province. It has advantages in natural resources with abundant water. There are nearly 1 million $\mathrm{Mu}$ water areas with the water quality reaching Standard III of national land water. The air quality is higher than Standard II of national level. The total soil is 3.59 million $\mathrm{Mu}$ and the soil is fertile. In 2003, the commissariat production reached 925,200 tons, the cotton, 13,700 tons, and the oil plants 37,100 tons. The annual production of agricultural straws is 1.04 million tons, with the obtainable 600,000 tons. 300,000 tons of it can be used as energy (power generation).

The project site, Daiyao Town, is located in the east of Xinghua City, which is the influxing area of three cities Xinghua, Dafeng and Dongtai. The area is 96.9 square meters with a population of 72,000 . The east of Daiyao Town is 204 national road, and in the west, Ningyan first class road, Ningjingyan highway, in the south, provincial, and in the north first class road. Also, Xinchang railway, national inner-river route is along the border. Therefore, the transportation is quite convenient.

The project is built in the industrial district of Daiyao Town. Within 30 kilometers, there are 300, 000 mu, producing 300,000 tons crops annually. The production of straws is approximately $330,000-350,000$ tons. The project only utilizes $10 \%$ of the total production. In addition, Daiyao Town has great numbers of milling plants with annual production of rice hulls 10, 000 tons. The rice hulls could be used directly as the raw materials for fluidized bed gasification. 


\subsection{Technical Process}

\subsubsection{Technical flow}

Air

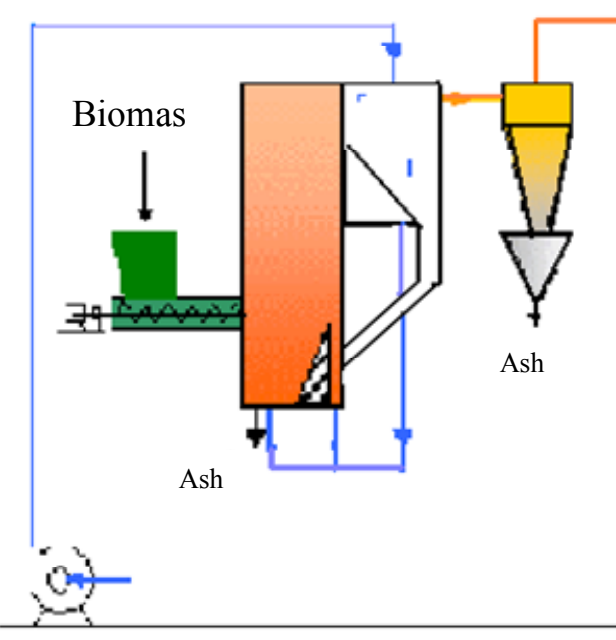

Water

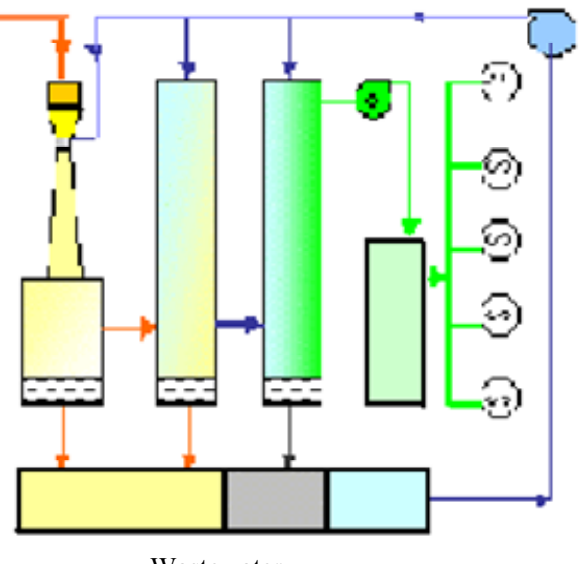

Wastewater

\subsubsection{Gasification power system}

The biomass circulating fluidized bed gasification combined power generation device consist of materials feeding device, steam generating devices, waste heat boiler, tar deep cracking device, gas cleaning device, air pre-heating device, gas generator, steam generator unit, circulating cooling water device, water treatment device, electric control system, waste water and residues treatment system.

\subsubsection{Device equipping Plan}

The proposed $4000 \mathrm{~kW}$ biomass gasification power plant will adopt the scheme of biomass gasification combined circulate power generation. The specific devices are:

- One circulating fluidized bed gasification boiler

- Six $500 \mathrm{kw}$ gas internal combustion generator (one is for spare wheel)

- One waste heat boiler

- One $1500 \mathrm{kw}$ steam turbine generator unit

Table 3-2-1 Energy consumption index of 4000 Biomass power plants

\begin{tabular}{|c|l|l|}
\hline No & \multicolumn{1}{|c|}{ Project } & \multicolumn{1}{c|}{ Parameter } \\
\hline 1 & Capacity of gas internal combustion generator unit $(\mathrm{kw})$ & $5 \mathrm{X} 500$ \\
\hline 2 & Capacity of steam turbine generator unit $(\mathrm{kw})$ & 1500 \\
\hline 3 & Power generation of the power plant per hour $(\mathrm{kwh} / \mathrm{h})$ & 4000 \\
\hline 4 & Power generation of the power plant per year $\left(10^{4} \mathrm{kwh} / \mathrm{y}\right)$ & $2600(6500$ hour $/$ year $)$ \\
\hline 5 & Electricity consuming ratio of the power plant $(\%)$ & 15 \\
\hline 6 & Feed-in electricity annually $\left(10^{4} \mathrm{kwh} / \mathrm{y}\right)$ & 2210 \\
\hline 7 & Biomass consumption for power generation $(\mathrm{kg} / \mathrm{kwh})$ & 1.1 \\
\hline 8 & Annual consumption of biomass $(\mathrm{t} / \mathrm{y})$ & 27000 \\
\hline 9 & Gross heat efficiency of the power plant $(\%)$ & 28 \\
\hline 10 & Annual replacement amount of standard coal $(\mathrm{t} / \mathrm{y})$ & 8000 \\
\hline 11 & Consumption of circulating water per hour $\left(\right.$ Yangtze river $\left.\mathrm{m}^{3} / \mathrm{h}\right)$ & 585 \\
\hline 12 & Consumption of other water resources per hour $\left(\right.$ tap water $\left.\mathrm{m}^{3} / \mathrm{h}\right)$ & 26 \\
\hline
\end{tabular}




\subsection{Feedstock collection system}

The feedstock includes two types, the one is rice husk, and the other is straw. The rice husk need not be process to gasify in the gasification boiler, and the straw nee be smashed to use. Furthermore, because the origin of rice husk and straw is different, the collection method and collection cost are different.

\subsubsection{Rice husk}

There are many small grinding rice mills near the power plant and surrounding area, which produce 100 tons rice husk every year. The small parts of the rice husk are sold for the feed process factory, and the other is use as the waste.

Through survey and negotiate, the purchase price of rice husk will be about 200 Yuan/tons. The price may increase to some extent. But the range of fluctuation will not be large because the object of purchaser is enterprise and the rice husk is the waste. Considering $10 \%$ increasing, the price will be 220 Yuan/tons.

The transportation cost of rice husk is 20 Yuan/tons, which includes the distance between grinding rice mill and collection site, and the collection site and power plant. The rice husk need be transferred by the collection site because the power plant cannot store all rice husk.

The maintenance cost of rice husk is about 30 Yuan/tons, which including the field, storehouse, keeper, management worker, anti-fire and profit of site.

In the range with 5-kilometer radius, the total amount of rice husk is about $8000-10000$ tons. From grinding rice mill to power plant, the collection cost is 250-207 Yuan/tons.

\subsubsection{Straw}

Xinhua is an agricultural country, which has abundant straw resource. The total amount of straw for generation power is about 300 thousand tons, which can meet with the demand of the power plant. The straw collection will adopts the tower structure, namely, agent will collect the straw from farmer, and then collection site purchase the straw form the agent.

The tem collection site will be established to charge with the purchase of straw and rice husk. The distance of the site is about 2-3 kilometer. Furthermore, the distance between the site and power plant is 5 kilometer.

Each site will manage 30-40 agents for collecting straw. The agent will be from the local farmer and charge with collecting the straw form the cultivated field. The straw will be delivered to the filed with the agent and dried to reach the demand for straw moisture.

Each agent will charge with 50 household farmers around the collection filed. The work of agent will include delivering the straw to the field owned by agents, and drying, stacking, and transportation to the collection site.

Based on the survey, the detailed collection cost is as follows:

- Purchase cost for raw straw: 50 Yuan/tons

- Agent cost: 70 Yuan/tons

- Collection site cost: 30Yuan/tons

- Profit of site: $15-20$ Yuan/tons

- Transportation cost from site to power plant: 10 Yuan/tons 
According to the above, the total cost of collection from cultivated filed to power plant is 180 Yuan/tons. The price increasing will be form directly collecting the straw from the farmer. The increasing rate is about $60 \%$, so the total cost is 201 Yuan/tons, which can be accepted by the power plant.

\subsection{Project construction}

\subsubsection{Site selection}

The initial decision of the plant site is in the industrial zone in the west of Daiyao Town, Xinghua City. The reasons are as follows:

- There are abundant raw materials

- The water resources are rich. The Chelu River can not only provide the water for production, but also providing water route for raw materials transportation

- Parts of public utilities could be utilized to reduce the initial investment.

\subsubsection{Transportation}

The project site, Daiyao Town, is located in the east of Xinghua City, which is the influxing area of three cities Xinghua, Dafeng and Dongtai. The area is 96.9 square meters with a population of 72,000. The east of Daiyao Town is 204 national road, and in the west, Ningyan first class road, Ningjingyan highway, in the south, provincial, and in the north first class road. Also, Xinchang railway, national inner-river route is along the border. Therefore, the transportation is quite convenient.

Both water route and highway can be used for transporting materials and equipments during the construction period of the power plant, as well as raw materials when in operation.

\subsection{Environmental impact analysis}

From the aspect of environment, utilizing biomass for power generation could obtain zero emission of $\mathrm{CO}_{2}$ and thus contribute to solve problem of the green house effect caused by over using fossil energy.

As the density of biomass materials is low, it will consume more energy during the transportation comparing with the conventional energy. This consumption cost considerably, and must not be neglected. Taking into consideration the energy used during transportation, smashing and drying process, it is estimated that the $\mathrm{CO}_{2}$ generated will be $90 \%$ less that of fossil energy. In addition, it could also reduce the emission of $\mathrm{CO}, \mathrm{SO}_{2}, \mathrm{NO}_{\mathrm{X}}$ and other pollutants. Therefore, it could contribute to improve the environment. 


\subsection{Investment estimation and financing resources}

\subsubsection{Investment estimation}

Table3-6-1 Investment estimation of 4000kw biomass power plant

\begin{tabular}{|l|l|c|}
\hline \multicolumn{1}{|c|}{ No } & \multicolumn{1}{|c|}{ Item } & Subtotal \\
\hline 1 & Investment in fixed assets & 3675.6 \\
\hline 1.1 & Project cost & 3063.0 \\
\hline 1.1 .1 & land and plant construction & 298.5 \\
\hline 1.1 .2 & Thermal power system & 1057.0 \\
\hline 1.1 .3 & Fuel supply system & 100.0 \\
\hline & Straw collection and smashing system & 100.0 \\
\hline 1.1 .4 & Dust removal system & 28.5 \\
\hline 1.1 .5 & Chemical water treatment system & 100.0 \\
\hline 1.1 .6 & Water supply system & 23.0 \\
\hline 1.1 .7 & Electric power system & 399.0 \\
\hline 1.1 .8 & Hat engineering controlled system & 100.0 \\
\hline 1.1 .9 & Fuel gas cleaning system & 200.0 \\
\hline 1.1 .10 & Cabinet & 120.0 \\
\hline 1.1 .11 & Others & 537.0 \\
\hline 1.2 & Provisional finance & 612.6 \\
\hline 1.2 .1 & Basic provisional finance $(12 \%)$ & 367.6 \\
\hline 1.2 .2 & Appreciation provisional finance $(8 \%)$ & 245.0 \\
\hline & 3nterest during construction & 75.6 \\
\hline & Total investment: $\mathbf{1 + 2 + 3}$ & $\mathbf{3 7 5 1 . 2}$ \\
\hline
\end{tabular}

Total investment of the project is 37.512 million Yuan, among which 36.756 million Yuan are invested in fixed assets; the interest during construction period is 756,000 Yuan.

\subsubsection{Financing}

The finance of this project is proposed to have $30 \%$ free finance (capital investment), which is 11.254 Yuan, $70 \%$ from the bank loan, which is 26.258 with the annual interest rate $5.76 \%$.

\subsection{Fiscal analysis}

\subsubsection{Basic data}

\subsubsection{Project lifetime}

The calculation period of this project is 15 years (exclusive of construction period), and the construction time frame is 12 months.

\subsubsection{Component of construction investment}

- Fixed assets investment: According to the calculation, it is around 36.756 Yuan

- The construction interest is the loan interest for the fixed assets investment. The interest during this period will be taken into account of total investment in fixed assets investment. It is calculated to be 756,000 Yuan.

- Total investment: It is 37.512 Yuan. 


\subsubsection{Operation cost}

Please refer to the table below for the operation cost of the project and the overall cost are included in the appendices.

Table 3-7-1 Operational cost of the 4000kw straw power plant

Unit: 10,000 yuan

\begin{tabular}{|l|l|c|c|r|r|}
\hline \multicolumn{1}{|c|}{ No } & \multicolumn{1}{|c|}{ Unit } & Annual cost & Unit price & Sub-total \\
\hline $\mathbf{1}$ & Input & & & & $\mathbf{9 7 1 . 8}$ \\
\hline 1.1 & Maintenance & & & & 70.0 \\
\hline 1.2 & Salary & & & & 100.0 \\
\hline 1.2 .1 & Administrative staff & $10^{4}$ yuan/man year & 8 & 2 & 16.0 \\
\hline 1.2 .2 & Operational staff & $10^{4}$ yuan/man year & 38 & 2 & 76.0 \\
\hline 1.2 .4 & Maintenance & $10^{4}$ yuan/man year & 4 & 2 & 8.0 \\
\hline 1.2 .3 & Assisting staff & $10^{4}$ yuan/man year & 10 & 2 & 20.0 \\
\hline 1.3 & Fuel \& power & & & & 801.8 \\
\hline 1.3 .2 & Water cost & Yuan/ton & 5687.5 & 1.2 & 0.7 \\
\hline 1.3 .3 & Pollutants treatment & Yuan/ton & 5687.5 & 0.6 & 0.3 \\
\hline 1.3 .4 & Raw material & Yuan/ton & 28600.0 & 280 & 800.8 \\
\hline 1.4 & Depreciation & & & & 232.8 \\
\hline $\mathbf{2}$ & Output & & & & $\mathbf{1 6 4 6 . 5}$ \\
\hline 2.1 & Electricity sale & yuan/kwh & 2210.0 & 0.714 & 1646.5 \\
\hline $\mathbf{3}$ & Tax & & & & $\mathbf{1 3 5 . 0}$ \\
\hline 3.1 & Value added tax & & & & 122.7 \\
\hline 3.1 .1 & Output tax (17\%) & & & & 239.2 \\
\hline 3.1 .2 & Input tax (17\%) & & & & 116.5 \\
\hline 3.2 & City maintenance & & & \\
\hline 3.3 & \& construction (7\%) & & & & 3.6 \\
\hline
\end{tabular}

\subsubsection{Fiscal assessment}

The feed-in tariff of this project is 0.745 Yuan $/ \mathrm{kwh}$. The internal rate of return (IRR) of the total finance is $6.06 \%$ (after tax), and $8.74 \%$ (before tax). The investment payback period is 11 years (after tax) and 9.63 years (before tax). Please refer to the appendices for cash flow.

The capital investment IRR of this project is $12.04 \%$ (after tax). The Fiscal net present value is 1.702 million Yuan. The payback period is 11.14 years. Please see the appendices for the project cash flow.

\subsubsection{Sensitivity analysis}

After analysis of four uncertain factors, i.e. production load, construction investment, feed in tariff, and interest rate of loan, it shows that the biggest factor is the feed in tariff to impact the economic benefits. As the renewable energy law has been in effect, and the project belongs to the renewable energy power generation, the access to the gird and the tariff could be guaranteed by the law. Therefore, the risk could be avoided. 
Table3-7-2 Sensitivity analysis of the $4000 \mathrm{kw}$ biomass power plant

\begin{tabular}{|c|c|c|c|c|c|}
\hline Uncertain factors & Changing ratio & Value & IRR & Changing ratio & Sensitivity coefficient \\
\hline \multirow{2}{*}{$\begin{array}{l}\text { Production load } \\
\text { (6500 hour/year) }\end{array}$} & $10 \%$ & 7150.0 & 14.68 & $21.93 \%$ & \multirow[b]{2}{*}{2.38} \\
\hline & $-10 \%$ & 5850.0 & 8.96 & $-25.58 \%$ & \\
\hline \multirow{2}{*}{$\begin{array}{l}\text { Construction investment } \\
\text { (36.756million yuan) }\end{array}$} & $10 \%$ & 4043.2 & 9.57 & $-20.51 \%$ & \multirow[b]{2}{*}{2.12} \\
\hline & $-10 \%$ & 3308.0 & 14.67 & $21.84 \%$ & \\
\hline \multirow{2}{*}{$\begin{array}{c}\text { Feed in tarrif } \\
(0.745 \text { yuan/kilo hour })\end{array}$} & $10 \%$ & 0.820 & 16.96 & $40.86 \%$ & \multirow[b]{2}{*}{5.13} \\
\hline & $-10 \%$ & 0.671 & 4.61 & $-61.71 \%$ & \\
\hline \multirow{2}{*}{$\begin{array}{c}\text { Interest rate of loan } \\
0.576 \%\end{array}$} & $10 \%$ & $0.634 \%$ & 11.96 & $-0.66 \%$ & \multirow[b]{2}{*}{0.08} \\
\hline & $-10 \%$ & $0.518 \%$ & 12.15 & $0.91 \%$ & \\
\hline
\end{tabular}

\subsubsection{Analysis of investment benefits}

Please see the table below for the analysis of the project investment benefits

Table 3-7-3 Investment benefits index of the $4000 \mathrm{kw}$ straw power plant

\begin{tabular}{|l|c|}
\hline \multicolumn{1}{|c|}{ Index } & Value $(\boldsymbol{\%})$ \\
\hline Annual average return & 164.2 \\
\hline Investment return rate & 4.4 \\
\hline Annual average profit tax & 380.1 \\
\hline Investment profit rate & 10.1 \\
\hline Capital investment return rate & 14.6 \\
\hline Capital investment profit tax rate & 33.8 \\
\hline
\end{tabular}

\subsection{Annex}

- Annex 3-1: Total cost

- Annex 3-2: Repay capital with interest of loan

- Annex 3-3: Profit and loss statement

- Annex 3-4: Cash flow (total capital)

- Annex 3-5: Cash flow (capital fund) 
Annex 1-1:Investment plan and financing

Unit: 10,000RMB

\begin{tabular}{|l|l|r|r|r|r|}
\hline \multirow{2}{*}{ No. Item } & & \multicolumn{2}{c|}{ Construction period } & Operation period & \multirow{2}{*}{ Total } \\
\cline { 3 - 5 } & & 1 & 2 & 3 & \\
\hline 1 & Total investment & 16325.52 & 16997.31 & & 33322.83 \\
\hline 1.1 & Fixed asset investment & 15996.40 & 15996.40 & & 31992.80 \\
\hline 1.2 & Regulation tax on fix asset investment direction & & & & \\
\hline 1.3 & Interest during construction period & 329.12 & 1000.91 & & 1330.03 \\
\hline 1.4 & Flow capital & & & & 0.00 \\
\hline 2 & Financing & 16325.52 & 16997.31 & & 33322.83 \\
\hline 2.1 & Self capital & 4897.66 & 5099.19 & & 9996.85 \\
\hline 2.2 & Bank loan & 11427.87 & 11898.12 & & 23325.98 \\
\hline 2.2 .1 & Long-term bank loan & 11427.87 & 11898.12 & & 23325.98 \\
\hline 2.2 .2 & Flow cash loan & & & & 0.00 \\
\hline 2.2 .3 & Other short-term loan & & & & \\
\hline 2.3 & Other & & & & \\
\hline
\end{tabular}

Annex1- 2:Operation cost and income

Unit: 10,000RMB

\begin{tabular}{|c|c|c|c|c|c|}
\hline No. & Item & Unit & Quantity & Unit price & Total \\
\hline 1 & Input & & & & 6442.56 \\
\hline 1.1 & $\mathrm{O} \& \mathrm{M}$ & & & & 202.62 \\
\hline 1.2 & Salary & $10,000 / \mathrm{a} /$ per capita & 150 & 2 & 300.00 \\
\hline 1.3 & Material & RMB/ton & 14 & 280 & 3913.73 \\
\hline 1.3 .1 & Collection & RMB/ton & 14 & 200 & 2795.52 \\
\hline 1.3 .2 & Package & RMB/ton & 14 & 30 & 419.33 \\
\hline 1.3 .3 & Transportation & $\mathrm{RMB} /$ ton & 14 & 50 & 698.88 \\
\hline 1.4 & Depreciation & & & & 2026.21 \\
\hline 2 & Output & & & & 10687.56 \\
\hline 2.2 & Electricity sale & $\mathrm{RMB} / \mathrm{kWh}$ & 13260 & 0.806 & 10687.56 \\
\hline 3 & Tax & & & & 1082.66 \\
\hline & 3.1 VAT & & & & 984.23 \\
\hline 3.1 .1 & Sale VAT rate $(13 \%)$ & & & & 1552.89 \\
\hline 3.1 .2 & Buy VAT rate $(17 \%)$ & & & & 568.66 \\
\hline & 3.2 Urban construction tax $(7 \%)$ & & & & 68.90 \\
\hline & 3.3 Education surtax $(3 \%)$ & & & & 29.53 \\
\hline
\end{tabular}


Annex 1-3: Total cost

Unit: 10,000RMB

\begin{tabular}{|c|c|c|c|c|c|c|c|c|c|c|c|c|c|c|c|c|c|c|c|c|c|}
\hline \multirow{2}{*}{ No. } & \multirow{2}{*}{ Item } & \multicolumn{2}{|c|}{$\begin{array}{c}\text { Construction } \\
\text { period }\end{array}$} & \multicolumn{18}{|c|}{ Operation period (full capacity) } \\
\hline & & 1 & 2 & 1 & 2 & 3 & 4 & 5 & 6 & 7 & 8 & 9 & 10 & 11 & 12 & 13 & 14 & 15 & 16 & 17 & 18 \\
\hline 1 & Fuel \& power & & & 3913.7 & 3913.7 & 3913.7 & 3913.7 & 3913.7 & 3913.7 & 3913.7 & 3913.7 & 3913.7 & 3913.7 & 3913.7 & 3913.7 & 3913.7 & 3913.7 & 3913.7 & 3913.7 & 3913.7 & 3913.7 \\
\hline 2 & Salary and welfare & & & 300.0 & 300.0 & 300.0 & 300.0 & 300.0 & 300.0 & 300.0 & 300.0 & 300.0 & 300.0 & 300.0 & 300.0 & 300.0 & 300.0 & 300.0 & 300.0 & 300.0 & 300.0 \\
\hline 4 & O\&M & & & 202.6 & 202.6 & 202.6 & 202.6 & 202.6 & 202.6 & 202.6 & 202.6 & 202.6 & 202.6 & 202.6 & 202.6 & 202.6 & 202.6 & 202.6 & 202.6 & 202.6 & 202.6 \\
\hline 5 & Depreciation & & & 2026.2 & 2026.2 & 2026.2 & 2026.2 & 2026.2 & 2026.2 & 2026.2 & 2026.2 & 2026.2 & 2026.2 & 2026.2 & 2026.2 & 2026.2 & 2026.2 & 2026.2 & 2026.2 & 2026.2 & 2026.2 \\
\hline 6 & Amortize cost & & & 0.0 & 0.0 & 0.0 & 0.0 & 0.0 & 0.0 & 0.0 & 0.0 & 0.0 & 0.0 & 0.0 & 0.0 & 0.0 & 0.0 & 0.0 & 0.0 & 0.0 & 0.0 \\
\hline 7 & Finance cost & 329.1 & 1000.9 & 1343.6 & 1241.1 & 1129.1 & 1006.8 & 873.3 & 727.3 & 568.0 & 393.8 & 203.7 & 0.0 & 0.0 & 0.0 & 0.0 & 0.0 & 0.0 & 0.0 & 0.0 & 0.0 \\
\hline 7.1 & Long-term loan interest & 329.1 & 1000.9 & 1343.6 & 1241.1 & 1129.1 & 1006.8 & 873.3 & 727.3 & 568.0 & 393.8 & 203.7 & 0.0 & 0.0 & 0.0 & 0.0 & 0.0 & 0.0 & 0.0 & 0.0 & 0.0 \\
\hline 7.2 & $\begin{array}{l}\text { Flow capital loan } \\
\text { interest }\end{array}$ & & & & & 0.0 & 0.0 & 0.0 & 0.0 & 0.0 & 0.0 & 0.0 & 0.0 & 0.0 & 0.0 & 0.0 & 0.0 & 0.0 & 0.0 & 0.0 & 0.0 \\
\hline 9 & Subtotal $(1+2+\ldots+9)$ & 329.1 & 1000.9 & 7786.1 & 7683.6 & 7571.7 & 7449.4 & 7315.8 & 7169.9 & 7010.5 & 6836.4 & 6646.2 & 6442.6 & 6442.6 & 6442.6 & 6442.6 & 6442.6 & 6442.6 & 6442.6 & 6442.6 & 6442.6 \\
\hline & Hereinto: Fixed cost & 0.0 & 0.0 & 2528.8 & 2528.8 & 2528.8 & 2528.8 & 2528.8 & 2528.8 & 2528.8 & 2528.8 & 2528.8 & 2528.8 & 2528.8 & 2528.8 & 2528.8 & 2528.8 & 2528.8 & 2528.8 & 2528.8 & 2528.8 \\
\hline 10 & $\begin{array}{l}\text { Operation cost } \\
(9-5-6-7)\end{array}$ & 0.0 & 0.0 & 4416.3 & 4416.3 & 4416.3 & 4416.3 & 4416.3 & 4416.3 & 4416.3 & 4416.3 & 4416.3 & 4416.3 & 4416.3 & 4416.3 & 4416.3 & 4416.3 & 4416.3 & 4416.3 & 4416.3 & 4416.3 \\
\hline
\end{tabular}




\begin{tabular}{|c|c|c|c|c|c|c|c|c|c|c|c|c|c|c|c|c|c|c|c|c|}
\hline \multirow{2}{*}{ Item } & \multicolumn{2}{|c|}{ Construction period } & \multicolumn{18}{|c|}{ Operation period (full capacity) } \\
\hline & 1 & 2 & 1 & 2 & 3 & 4 & 5 & 6 & 7 & 8 & 9 & 10 & 11 & 12 & 13 & 14 & 15 & 16 & 17 & 18 \\
\hline \multicolumn{21}{|l|}{ Repaying loan and interest } \\
\hline $\begin{array}{l}\text { Accumulative loan and interest in } \\
\text { beginning year }\end{array}$ & 0.0 & 11427.9 & 23326.0 & 21546.6 & 19603.0 & 17479.91 & 15160.71 & 12627.5 & 9860.3 & 6837.6 & 63535.9 & 0.0 & 0.0 & 0.0 & 0.0 & 0.0 & 0.0 & 0.0 & 0.0 & 0.0 \\
\hline Loan & 0.0 & 11427.9 & 23326.0 & 21546.6 & 19603.0 & 17479.91 & 15160.71 & 12627.5 & 9860.3 & 6837.6 & 63535.9 & 0.0 & 0.0 & 0.0 & 0.0 & 0.0 & 0.0 & 0.0 & 0.0 & 0.0 \\
\hline Interest of construction period & & 329.1 & 1000.9 & & & & & & & & & & & & & & & & & \\
\hline Annual loan & 11427.9 & 11898.1 & 0.0 & & & & & & & & & & & & & & & & & \\
\hline Interest & 329.1 & 1000.9 & 1343.6 & 1241.1 & 1129.1 & 1006.8 & 873.3 & 727.3 & 568.0 & 393.8 & 203.7 & 0.0 & 0.0 & 0.0 & 0.0 & 0.0 & 0.0 & 0.0 & 0.0 & 0.0 \\
\hline Return loan & 0.0 & 0.0 & 1779.4 & 1943.6 & 2123.1 & 2319.1 & 2533.3 & 2767.2 & 3022.7 & 3301.8 & 3535.9 & 0.0 & 0.0 & 0.0 & 0.0 & 0.0 & 0.0 & 0.0 & 0.0 & 0.0 \\
\hline Return interest & 329.1 & 1000.9 & 1343.6 & 1241.1 & 1129.1 & 1006.8 & 873.3 & 727.3 & 568.0 & 393.8 & 8203.7 & 0.0 & 0.0 & 0.0 & 0.0 & 0.0 & 0.0 & & & \\
\hline Capital source for repay loan & & & 3122.9 & 3184.7 & 3252.2 & 3326.0 & 3406.5 & 3494.5 & 3590.6 & 3695.6 & 63810.3 & 3933.1 & 13933.1 & 3933.1 & 3933.1 & 3933.1 & 13933.1 & 3933.1 & 13933.13 & 3933.1 \\
\hline Profit & & & 1096.7 & 1158.5 & 1226.0 & 1299.8 & 1380.3 & 1468.3 & 1564.4 & 1669.4 & 1784.1 & 1906.9 & 906.9 & 1906.9 & 1906.9 & 1906.9 & 906.9 & 1906.9 & 91906.9 & 1906.9 \\
\hline Amortize & & & 2026.2 & 2026.2 & 2026.2 & 2026.2 & 2026.2 & 2026.2 & 2026.2 & 2026.2 & 2026.2 & 2026.2 & 2026.2 & 2026.2 & 2026.2 & 2026.2 & 2026.2 & 2026.2 & 22026.2 & 2026.2 \\
\hline Depreciation & & & 0.0 & 0.0 & 0.0 & 0.0 & 0.0 & 0.0 & 0.0 & 0.0 & 0.0 & 0.0 & 0.0 & 0.0 & 0.0 & 0.0 & 0.0 & 0.0 & 0.0 & 0.0 \\
\hline
\end{tabular}


Annex 1-5: Profit and loss statement

Unit: 10,000RMB

\begin{tabular}{|c|c|c|c|c|c|c|c|c|c|c|c|c|c|c|c|c|c|c|c|c|c|}
\hline \multirow[t]{2}{*}{ Item } & \multicolumn{2}{|c|}{$\begin{array}{c}\text { Construction } \\
\text { period }\end{array}$} & \multicolumn{19}{|c|}{ Operation period (full capacity) } \\
\hline & 1 & 2 & 1 & 2 & 3 & 4 & 5 & 6 & 7 & 8 & 9 & 10 & 11 & 12 & 13 & 14 & 15 & 16 & 17 & 18 & 合计 \\
\hline Selling income & & & 10688 & 10688 & 10688 & 10688 & 10688 & 10688 & 10688 & 10688 & 10688 & 10688 & 10688 & 10688 & 10688 & 10688 & 10688 & 10688 & 10688 & 10688 & 1828289 \\
\hline Total cost & 329 & 1001 & 7786 & 7684 & 7572 & 7449 & 7316 & 7170 & 7011 & 6836 & 6646 & 6443 & 6443 & 6443 & 6443 & 6443 & 6443 & 6443 & 6443 & 6443 & 125657.4 \\
\hline VAT & & & 1819 & 1921 & 2033 & 2156 & 2289 & 2435 & 2594 & 2768 & 2959 & 3162 & 3162 & 3162 & 3162 & 3162 & 3162 & 3162 & 3162 & 3162 & 45618.1 \\
\hline Profit & & & 600 & 634 & 671 & 711 & 755 & 804 & 856 & 914 & 976 & 1044 & 1044 & 1044 & 1044 & 1044 & 1044 & 1044 & 1044 & 1044 & 15054.0 \\
\hline Income tax & & & 1219 & 1287 & 1362 & 1444 & 1534 & 1631 & 1738 & 1855 & 1982 & 2119 & 2119 & 2119 & 2119 & 2119 & 2119 & 2119 & 2119 & 2119 & 30564.1 \\
\hline $\begin{array}{ll}\text { Profit after } \\
\text { income tax }\end{array}$ & & & 1219 & 1287 & 1362 & 1444 & 1534 & 1631 & 1738 & 1855 & 1982 & 2119 & 2119 & 2119 & 2119 & 2119 & 2119 & 2119 & 2119 & 2119 & 30564.1 \\
\hline Distributed profit & & & 122 & 129 & 136 & 144 & 153 & 163 & 174 & 185 & 198 & 212 & 212 & 212 & 212 & 212 & 212 & 212 & 212 & 212 & 30564 \\
\hline $\begin{array}{l}\text { Surplus } \\
\text { accumulation } \\
\text { fund }\end{array}$ & & & & & & & & & & & & & & & & & & & & & 0.0 \\
\hline $\begin{array}{l}\text { No distributed } \\
\text { profit }\end{array}$ & & & 1097 & 1159 & 1226 & 1300 & 1380 & 1468 & 1564 & 1669 & 1784 & 1907 & 1907 & 1907 & 1907 & 1907 & 1907 & 1907 & 1907 & 1907 & 27507.7 \\
\hline $\begin{array}{l}\text { Accumulated } \\
\text { non-distributed } \\
\text { profit }\end{array}$ & & & 1097 & 2255 & 3481 & 4781 & 6161 & 7630 & 9194 & 10863 & 12648 & 14554 & 16461 & 18368 & 20275 & 22182 & 24089 & 25996 & 27903 & 29810 & 235420 \\
\hline
\end{tabular}

\begin{tabular}{|l|l|c|}
\hline Calculation indicators & Investment profit rate (\%) & 4.97 \\
\cline { 2 - 3 } & Investment tax rate (\%) & 10.94 \\
\hline
\end{tabular}


Annex1-6: Cash flow (capital fund)

Unite: 10,000RMB

\begin{tabular}{|c|c|c|c|c|c|c|c|c|c|c|c|c|c|c|c|c|c|c|c|c|c|}
\hline \multirow{2}{*}{ No. } & \multirow{2}{*}{ Item } & \multicolumn{2}{|c|}{ Construction period } & \begin{tabular}{|c|}
$\begin{array}{c}\text { Operation } \\
\text { period }\end{array}$ \\
\end{tabular} & \multirow[b]{2}{*}{2} & \multirow[b]{2}{*}{3} & \multirow[b]{2}{*}{4} & \multirow[b]{2}{*}{5} & \multirow[b]{2}{*}{6} & \multirow[b]{2}{*}{7} & \multirow[b]{2}{*}{8} & \multirow[b]{2}{*}{9} & \multirow[b]{2}{*}{10} & \multirow[b]{2}{*}{11} & \multirow[b]{2}{*}{12} & \multirow[b]{2}{*}{13} & \multirow[b]{2}{*}{14} & \multirow[b]{2}{*}{15} & \multirow[b]{2}{*}{16} & \multirow[b]{2}{*}{17} & \multirow[b]{2}{*}{18} \\
\hline & & 1 & 2 & 1 & & & & & & & & & & & & & & & & & \\
\hline 1 & Cash inflow & & & 10687.6 & 10687.6 & 10687.6 & 10687.6 & 10687.6 & 10687.6 & 10687.6 & 10687.6 & 10687.6 & 10687.6 & 10687.6 & 10687.6 & 10687.6 & 10687.6 & 10687.6 & 10687.6 & 10687.6 & 10687.6 \\
\hline 1.1 & Selling income & & & 10687.6 & 10687.6 & 10687.6 & 10687.6 & 10687.6 & 10687.6 & 10687.6 & 10687.6 & 10687.6 & 10687.6 & 10687.6 & 10687.6 & 10687.6 & 10687.6 & 10687.6 & 10687.6 & 10687.6 & 10687.6 \\
\hline 2 & Cash outflow & & & & & & & & & & & & & & & & & & & & \\
\hline 2.1 & Self capital & & & & & & & & & & & & & & & & & & & & \\
\hline 2.2 & Principal payback & 5226.8 & 6100.1 & 9222.1 & 9317.7 & 9422.2 & 9536.3 & 9660.9 & 9797.1 & 9945.8 & 10108.2 & 10214.9 & 6542.6 & 6542.6 & 6542.6 & 6542.6 & 6542.6 & 6542.6 & 6542.6 & 6542.6 & 6542.6 \\
\hline 2.3 & Loan interest & 4897.7 & 5099.2 & 0.0 & & & & & & & & & & & & & & & & & \\
\hline 2.4 & Operation cost & 0.0 & 0.0 & 1779.4 & 1943.6 & 2123.1 & 2319.1 & 2533.3 & 2767.2 & 3022.7 & 3301.8 & 3535.9 & 0.0 & 0.0 & 0.0 & 0.0 & 0.0 & 0.0 & 0.0 & 0.0 & \\
\hline 2.5 & $\begin{array}{l}\text { Sale income tax and } \\
\text { surtax }\end{array}$ & 329.1 & 1000.9 & 1343.6 & 1241.1 & 1129.1 & 1006.8 & 873.3 & 727.3 & 568.0 & 393.8 & 203.7 & 0.0 & 0.0 & 0.0 & 0.0 & 0.0 & 0.0 & 0.0 & 0.0 & 0.0 \\
\hline 2.6 & Income tax & 0.0 & 0.0 & 4416.3 & 4416.3 & 4416.3 & 4416.3 & 4416.3 & 4416.3 & 4416.3 & 4416.3 & 4416.3 & 4416.3 & 4416.3 & 4416.3 & 4416.3 & 4416.3 & 4416.3 & 4416.3 & 4416.3 & 4416.3 \\
\hline 3 & Net cash flow & 0.0 & 0.0 & 1082.7 & 1082.7 & 1082.7 & 1082.7 & 1082.7 & 1082.7 & 1082.7 & 1082.7 & 1082.7 & 1082.7 & 1082.7 & 1082.7 & 1082.7 & 1082.7 & 1082.7 & 1082.7 & 1082.7 & 1082.7 \\
\hline 4 & \begin{tabular}{|l}
$\begin{array}{l}\text { Accumulated } \\
\text { cash flow }\end{array}$ \\
\end{tabular} & 0.0 & 0.0 & 600.2 & 634.0 & 671.0 & 711.3 & 755.4 & 803.6 & 856.1 & 913.6 & 976.4 & 1043.6 & 1043.6 & 1043.6 & 1043.6 & 1043.6 & 1043.6 & 1043.6 & 1043.6 & 1043.6 \\
\hline & & -5226.8 & -6100.1 & 1465.4 & 1369.8 & 1265.4 & 1151.3 & 1026.6 & 890.5 & 741.8 & 579.3 & 472.7 & 4145.0 & 4145.0 & 4145.0 & 4145.0 & 4145.0 & 4145.0 & 4145.0 & 4145.0 & 4145.0 \\
\hline & & -5226.8 & -11326.9 & -9861.4 & -8491.6 & -7226.3 & -6075.0 & -5048.4 & -4157.9 & -3416.1 & -2836.8 & -2364.1 & 1780.9 & 5925.8 & 10070.8 & 14215.8 & 18360.8 & 22505.8 & 26650.8 & 30795.7 & 34940.7 \\
\hline
\end{tabular}

\begin{tabular}{|l|l|c|}
\hline \multirow{4}{*}{ Calculation indicators } & FIRR & $12.00 \%$ \\
\cline { 2 - 3 } & Financial net value (ic=10\%) & 6702.69 \\
\cline { 2 - 3 } & Pt(year) & 9.6 \\
\hline
\end{tabular}


Annex 1-7: Cash flow (total capital)

Unit: 10,000RMB

\begin{tabular}{|c|c|c|c|c|c|c|c|c|c|c|c|}
\hline \multirow[b]{2}{*}{ No. } & \multirow[b]{2}{*}{ Item } & \multicolumn{2}{|c|}{$\begin{array}{l}\text { Construction } \\
\text { period }\end{array}$} & \multirow[b]{2}{*}{1} & \multirow[b]{2}{*}{2} & \multirow{2}{*}{\multicolumn{2}{|c|}{3}} & \multirow[b]{2}{*}{4} & \multirow[b]{2}{*}{5} & \multirow[b]{2}{*}{6} & \multirow[b]{2}{*}{7} \\
\hline & & 1 & 2 & & & & & & & & \\
\hline 1 & Cash inflow & 0.0 & 0.0 & 10687.6 & 10687.6 & \multicolumn{2}{|c|}{10687.6} & 10687.6 & 10687.6 & 10687.6 & 1068 \\
\hline 1.1 & Sale income & & & 10687.6 & 10687.6 & \multicolumn{2}{|c|}{10687.6} & 10687.6 & 10687.6 & 10687.6 & 1068 \\
\hline 2 & Cash outflow & 16325.5 & 16997.3 & 7442.8 & 7374.1 & \multicolumn{2}{|c|}{7299.1} & 7217.2 & 7127.7 & 7029.9 & 692 \\
\hline 2.1 & Fixed asset investment & 16325.5 & 16997.3 & 1343.6 & 1241.1 & \multicolumn{2}{|c|}{1129.1} & 1006.8 & 873.3 & 727.3 & 56 \\
\hline 2.2 & Flow capital & & & 0.0 & & & & & & & \\
\hline 2.3 & Sale tax & & & 1082.7 & 1082.7 & \multicolumn{2}{|c|}{1082.7} & 1082.7 & 1082.7 & 1082.7 & 108 \\
\hline 2.4 & 4 Operation cost & & & 4416.3 & 4416.3 & \multicolumn{2}{|c|}{4416.3} & 4416.3 & 4416.3 & 4416.3 & 441 \\
\hline 2.5 & Income tax & 0.0 & 0.0 & 600.2 & 634.0 & \multicolumn{2}{|c|}{671.0} & 711.3 & 755.4 & 803.6 & 85 \\
\hline & Net cash flow value & -16325.5 & -16997.3 & 3244.8 & 3313.5 & \multicolumn{2}{|c|}{3388.5} & 3470.4 & 3559.9 & 3657.7 & 376 \\
\hline & $\begin{array}{l}\text { Accumulated net cash flow } \\
\text { value }\end{array}$ & -16325.5 & -33322.8 & -30078.0 & -26764.6 & -2337 & & -19905.7 & -16345.8 & -12688.2 & -892 \\
\hline & $\begin{array}{l}\text { Net cash flow value before } \\
\text { taxation }\end{array}$ & -16325.5 & -16997.3 & 3845.0 & 3947.5 & 405 & 59.4 & 4181.7 & 4315.3 & 4461.2 & 462 \\
\hline & $\begin{array}{l}\text { Accumulated net cash flow } \\
\text { value before taxation }\end{array}$ & -16325.5 & -33322.8 & -29477.9 & -25530.4 & -2147 & & -17289.2 & -12973.9 & -8512.7 & -389 \\
\hline & & Calcula & ation inc & dicator: & & & & ter taxa & $\operatorname{tion}_{\mathrm{Be}}$ & ore tax & ation \\
\hline & FIRR（\%) & & & & & & & $6.75 \%$ & & $9.66 \%$ & \\
\hline & Financial n & et value & $\left(\mathrm{Ic}=10^{\circ}\right.$ & o) $(10$ & ,000RN & IB ） & & 1705 & & 8955 & \\
\hline & Pt(year) & & & & & & & 9.25 & & 8.81 & \\
\hline
\end{tabular}


Annex 2-1: Investment

Unit: $10^{4}$ Yuan

\begin{tabular}{|c|c|c|c|c|c|c|c|c|c|}
\hline \multirow[b]{2}{*}{ No. } & \multirow[b]{2}{*}{ Engineering or cost } & \multicolumn{7}{|c|}{ Estimated value } & \multirow[b]{2}{*}{ Remarks } \\
\hline & & Construction & $\begin{array}{l}\text { Equipment } \\
\text { purchasing }\end{array}$ & Installation & Others & Total & $\begin{array}{c}\begin{array}{c}\text { Area of construction } \\
\left(\mathbf{M}^{2}\right)\end{array} \\
\end{array}$ & Unit cost & \\
\hline 1 & Investment of fixed assets & 169.20 & 2061.50 & 229.80 & 853.91 & 3314.41 & 1870.00 & & \\
\hline 1.1 & Cost of engineering & 169.20 & 2061.50 & 229.80 & & 2460.50 & & & \\
\hline 1.1.1 & Production & 127.00 & 1944.50 & 213.50 & & 2285.00 & & & \\
\hline 1.1.1.1 & Gasification & 80.00 & 320.40 & 80.10 & & 480.50 & 800.00 & 1000.00 & \\
\hline 1.1.1.2 & Power generation & 15.00 & 937.35 & 104.15 & & 1056.50 & 150.00 & 1000.00 & \\
\hline 1.1.1.3 & Gas purification & 4.00 & 165.75 & 29.25 & & 199.00 & 100.00 & 400.00 & \\
\hline 1.1.1.4 & Raw material preparation & 24.00 & 5.00 & 0.00 & & 29.00 & 400.00 & 600.00 & \\
\hline 1.1.1.5 & Crushing and briquette machines & & 466.00 & & & 466.00 & & & \\
\hline 1.1.1.6 & $\begin{array}{l}\begin{array}{l}\text { Power transforming and } \\
\text { transmission }\end{array} \\
\end{array}$ & 4.00 & 50.00 & 0.00 & & 54.00 & 50.00 & 800.00 & \\
\hline 1.1.2 & Civil engineering & 15.20 & 53.00 & 16.30 & & 84.50 & & & \\
\hline 1.1.2.1 & Water supply and discharging & 3.20 & 41.00 & 11.10 & & 55.30 & & & \\
\hline 1.1.2.1.1 & Water discharging network in plant & & 1.20 & 5.00 & 2.50 & & 8.70 & 20.00 & 600.00 \\
\hline 1.1.2.1.2 & Waste water disposal system & 2.00 & 28.00 & 7.00 & & 37.00 & 50.00 & 400.00 & \\
\hline 1.1.2.1.3 & $\begin{array}{l}\text { Water for fire-fighting and safety } \\
\text { system }\end{array}$ & & 8.00 & 1.60 & & 9.60 & & & \\
\hline 1.1.2.2 & Power line and lighting in plant & & 8.00 & 3.20 & & 11.20 & & & \\
\hline 1.1.2.3 & General plan & 12.00 & & & & 12.00 & & & \\
\hline 1.1.2.3.1 & Wall and gate & 2.00 & & & & 2.00 & & & \\
\hline 1.1.2.3.2 & Road inside plant & 10.00 & & & & 10.00 & & & \\
\hline 1.1.2.4 & Power use system in plant & & 4.00 & 2.00 & & 6.00 & & & \\
\hline 1.1.3 & Service engineering & 27.00 & 64.00 & $\mathbf{0 . 0 0}$ & & 91.00 & & & \\
\hline 1.1.3.1 & Office & 18.00 & & & & 18.00 & 300.00 & 600.00 & \\
\hline 1.1.3.2 & Engineering outside plant & 9.00 & & & & 9.00 & & & \\
\hline 1.1.3.2.1 & Road outside plant & 2.00 & & & & 2.00 & & & \\
\hline
\end{tabular}




\begin{tabular}{|c|c|c|c|c|c|c|c|c|}
\hline 1.1.3.2.2 & Pipeline & 2.00 & & & & 2.00 & & \\
\hline 1.1.3.2.3 & Vegetation & 5.00 & & & & 5.00 & & \\
\hline 1.1 .3 .3 & Office equipment & & 10.00 & & & 10.00 & & \\
\hline 1.1.3.4 & Purchasing cost of tool and furniture & & 14.00 & & & 14.00 & & \\
\hline 1.1 .2 .5 & Cost of spare parts & & 40.00 & & & 40.00 & & \\
\hline 1.2 & Others & & & & 479.24 & 479.24 & & \\
\hline 1.2 .1 & Cost of production preparation & & & & 40.00 & 40.00 & & \\
\hline 1.2 .2 & Cost of engineering design & & & & 123.03 & 123.03 & & 0.05 \\
\hline 1.2 .3 & Cost of earliest stage works & & & & 20.00 & 20.00 & & \\
\hline 1.2 .5 & Cost of land & & & & 60.00 & 60.00 & 15.00 & 亩 \\
\hline 1.2 .6 & Cost of construction management & & & & 24.61 & 24.61 & & 0.01 \\
\hline 1.2 .7 & Cost of construction monitoring & & & & 24.61 & 24.61 & & 0.01 \\
\hline 1.2 .8 & Cost of research \& experiment & & & & 187.00 & 187.00 & & \\
\hline 1.3 & Cost of preparation & & & & 374.68 & 374.68 & & \\
\hline 1.3 .1 & Cost of basic preparation & & & & 235.18 & 235.18 & & 0.08 \\
\hline 1.3 .2 & Prepared cost for price raise & & & & 139.50 & 139.50 & & 0.06 \\
\hline \multirow[t]{2}{*}{2} & $\begin{array}{l}\text { Regulating tax of investment for } \\
\text { fixed assets }\end{array}$ & & & & $\mathbf{0 . 0 0}$ & & & 0.01 \\
\hline & Total & 169.20 & 2061.50 & 229.80 & 853.91 & 3314.41 & & \\
\hline
\end{tabular}


Annex 2-2:Operation coat and income

\begin{tabular}{|l|l|c|c|c|c|}
\hline No. & \multicolumn{1}{|c|}{ Items } & Unit & Annual use & Unit price & Sum \\
\hline $\mathbf{1}$ & Input & & & & $\mathbf{1 0 6 8 . 0 8}$ \\
\hline 1.1 & Cost of maintenance & & & & 20.99 \\
\hline 1.2 & Salary & & & & 74.40 \\
\hline 1.2 .1 & Managing staffs & $10^{4}$ Yuan/person.yr. & 4 & 2.4 & 9.60 \\
\hline 1.2 .2 & Leader of group & $10^{4}$ Yuan/person.yr. & 16 & 1.8 & 28.80 \\
\hline 1.2 .4 & Operation workers & $10^{4}$ Yuan/person.yr. & 30 & 1.2 & 36.00 \\
\hline 1.2 .3 & Auxiliary workers & $10^{4}$ Yuan/person.yr. & 40 & 0.96 & 38.40 \\
\hline 1.3 & Fuel \& power & & & & 972.69 \\
\hline 1.3 .1 & Electricity & $10^{4} \mathrm{kwh}$ & 104 & 0.73 & 75.92 \\
\hline 1.3 .2 & Water fee & Yuan/t & 8760 & 1.2 & 1.05 \\
\hline 1.3 .3 & Pollution discharging fee & Yuan/t & 8760 & 0.6 & 0.53 \\
\hline 1.3 .4 & Cost of engine oil & Yuan/Kg & 43200 & 9 & 38.88 \\
\hline 1.3 .5 & Cost of raw material & Yuan/t & 28543.7 & 300 & 856.31 \\
\hline 1.4 & Cost of depreciation & & & & 209.91 \\
\hline 2 & Output & & & & $\mathbf{1 7 2 4 . 4 9}$ \\
\hline 2.1 & Power sales & Yuan/kWh & 2288.0 & 0.727 & 1663.38 \\
\hline 2.2 & Tar oil & Yuan/t & 611.1 & 1000 & 61.11 \\
\hline $\mathbf{3}$ & Tax & & & & $\mathbf{1 2 0 . 1 6}$ \\
\hline 3.1 & Value-added tax & & & & 109.24 \\
\hline 3.2 & City construction tax (7\%) & & & $3 \%$ & 2.82 \\
\hline 3.3 Education surcharge $(3 \%)$ & & & $\mathbf{3 0 \%}$ \\
\hline 3.3 & Education surcharge & & & & 7.65 \\
\hline $\mathbf{4}$ & Income tax & & & & \\
\hline
\end{tabular}


Annex2-3: Total cost

Unit: 10,000RMB

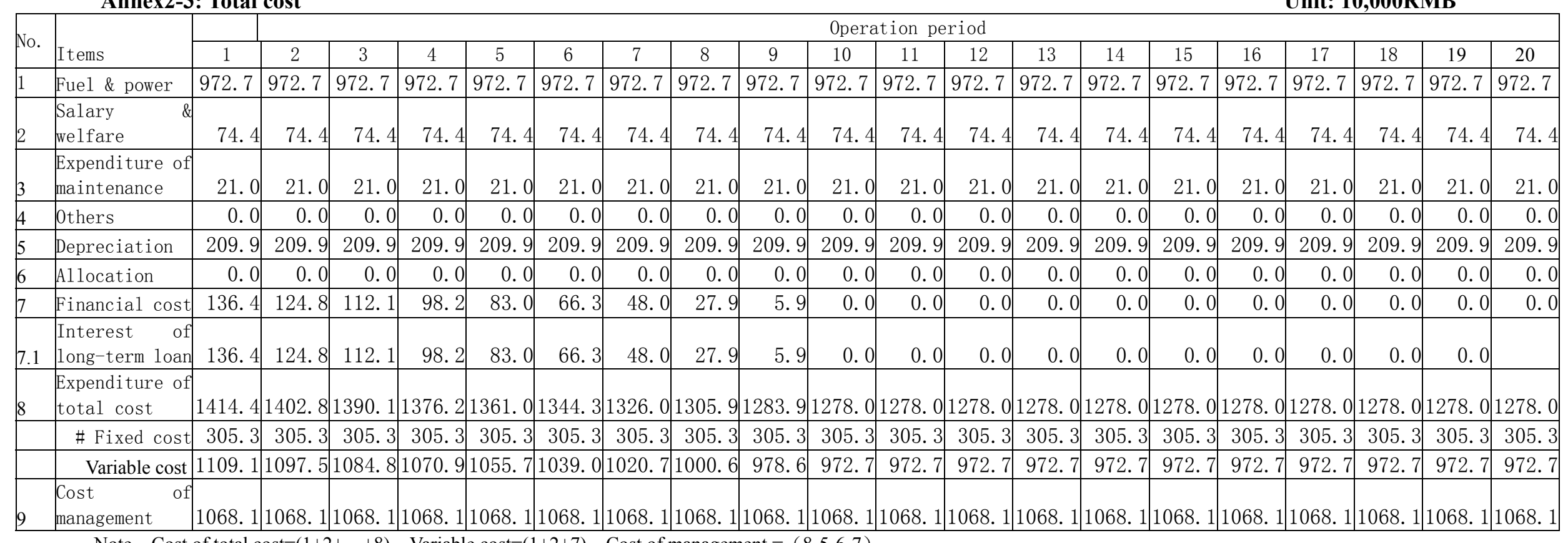

Note: Cost of total cost $=(1+2+\ldots+8) ; \quad$ Variable cost $=(1+2+7) ; \quad$ Cost of management $=(8-5-6-7)$ 
Annex 2-4:Cash Flow (Total capital)

Unit:: $10^{4}$ Yuan

\begin{tabular}{|c|c|c|c|c|c|c|c|c|c|c|c|c|c|c|c|c|c|c|c|c|c|c|}
\hline \multirow[b]{2}{*}{ No. } & \multicolumn{2}{|c|}{ Year Construction } & \multicolumn{20}{|c|}{ Production reaching design capacity } \\
\hline & Items & 1 & 1 & 2 & 3 & 4 & 5 & 6 & 7 & 8 & 9 & 10 & 11 & 12 & 13 & 14 & 15 & 16 & 17 & 18 & 19 & 20 \\
\hline 1 & Cash inflow & 0 & 1724 & 1724 & 1724 & 1724 & $4 \quad 1724$ & 1724 & 1724 & 1724 & 1724 & 1724 & 1724 & 1724 & 1724 & 1724 & 1724 & 1724 & 1724 & 1724 & 1724 & 1724 \\
\hline 1.1 & Income & & 1724 & 1724 & 1724 & 1724 & 1724 & 1724 & 1724 & 1724 & 1724 & 1724 & 1724 & 1724 & 1724 & 1724 & 1724 & 1724 & 1724 & 1724 & 1724 & 1724 \\
\hline 2 & Cash outflow & 3383 & 1387 & 1380 & 1371 & 1362 & 1352 & 1340 & 1328 & 1315 & 1322 & 1302 & 1296 & 1296 & 1296 & 1296 & 1296 & 1296 & 1296 & 1296 & 1296 & 1296 \\
\hline 2.1 & Fixed asset & 3383 & & & & & & & & & & & & & & & & & & & & \\
\hline 2.3 & VAT and addtion & & 120 & 120 & 120 & 120 & 120 & 120 & 120 & 120 & 120 & 120 & 120 & 120 & 120 & 120 & 120 & 120 & 120 & 120 & 120 & 120 \\
\hline & Interest & & 136 & 125 & 112 & 98 & 83 & 66 & 48 & 28 & 28 & 6 & & & & & & & & & & \\
\hline 2.4 & Running cost & & 1068 & 1068 & 1068 & 1068 & 1068 & 1068 & 1068 & 1068 & 1068 & 1068 & 1068 & 1068 & 1068 & 1068 & 1068 & 1068 & 1068 & 1068 & 1068 & 1068 \\
\hline 2.5 & Income tax & & 63 & 67 & 71 & 75 & 80 & 86 & 92 & 98 & 106 & 108 & 108 & 108 & 108 & 108 & 108 & 108 & 108 & 108 & 108 & 108 \\
\hline 3 & Net cash flow & -3383 & 337 & 345 & 353 & 363 & 373 & 384 & 396 & 410 & 403 & 423 & 429 & 429 & 429 & 429 & 429 & 429 & 429 & 429 & 429 & 429 \\
\hline 4 & $\begin{array}{l}\text { Accumulated net cash } \\
\text { flow }\end{array}$ & -3383 & -3045 & -2700 & -2347 & -1984 & $4 \mid-1611$ & -1227 & -831 & -421 & -18 & 404 & 833 & 1261 & 1690 & 2118 & 2547 & 2976 & 3404 & 3833 & 4261 & 4690 \\
\hline & $\begin{array}{l}\text { Net cash flow before } \\
\text { income tax }\end{array}$ & -3383 & 400 & 411 & 424 & 438 & 453 & 470 & 488 & 508 & 508 & 530 & 536 & 536 & 536 & 536 & 536 & 536 & 536 & 536 & 536 & 536 \\
\hline & $\begin{array}{l}\text { Accumulated net cash } \\
\text { flow before income } \\
\text { tax }\end{array}$ & -3383 & -2983 & -2571 & -2147 & $-170 s$ & \begin{tabular}{|l|l|}
9 & -1256 \\
\end{tabular} & -786 & -298 & 211 & 719 & 1249 & 1785 & 2322 & 2858 & 3394 & 3930 & 4467 & 5003 & 5539 & 6075 & 6612 \\
\hline & Index & & & & After & incom & ne $\operatorname{tax}$ & & & & & & & & & Before & incon & ne tax & & & & \\
\hline & IRR & & & & & $7.59 \%$ & & & & & & & & & & & $10.85 \%$ & & & & & \\
\hline & NPV Ic $=6 \%\left(10^{4}\right.$ Yuan $)$ & & & & 3. $58 \mathrm{Mi}$ & illiol & n Yuan & & & & & & & & & 1.661 & lillio & n Yuar & & & & \\
\hline & $\begin{array}{|ll|}\begin{array}{l}\text { Payback } \\
\text { (year) }\end{array} & \text { period } \\
\end{array}$ & & & & 9.0 & 4 уеа & & & & & & & & & & & 59 уеа & & & & & \\
\hline
\end{tabular}


Annex2-5: Cash Flow (Capital Fund)

Unit: $10^{4}$ Yuan

\begin{tabular}{|c|c|c|c|c|c|c|c|c|c|c|c|c|c|c|c|c|c|c|c|c|c|c|}
\hline \multirow{2}{*}{ No. } & \multirow{2}{*}{ Iitems } & Construction & \multicolumn{20}{|c|}{ Operation period } \\
\hline & & 1 & 1 & 2 & 3 & 4 & 5 & 6 & 7 & 8 & 9 & 10 & 11 & 12 & 13 & 14 & 15 & 16 & 17 & 18 & 19 & 20 \\
\hline 1 & Cash inflow & 0 & 1724 & 1724 & 1724 & 1724 & 1724 & 1724 & 1724 & 1724 & 1724 & 1724 & 1724 & 1724 & 1724 & 1724 & 1724 & 1724 & 1724 & 1724 & 1724 & 1724 \\
\hline 1.1 & Income & 0 & 1724 & 1724 & 1724 & 1724 & 1724 & 1724 & 1724 & 1724 & 1724 & 1724 & 1724 & 1724 & 1724 & 1724 & 1724 & 1724 & 1724 & 1724 & 1724 & 1724 \\
\hline 2 & Cash outflow & 1083 & 1588 & 1600 & 1612 & 1626 & 1641 & 1658 & 1676 & 1697 & 1704 & 1405 & 1296 & 1296 & 1296 & 1296 & 1296 & 1296 & 1296 & 1296 & 1296 & 1296 \\
\hline 2.1 & Self-owned capital & 1015 & & & & & & & & & & & & & & & & & & & & \\
\hline 2.2 & Repayment of capital & 0 & 201 & 220 & 241 & 264 & 290 & 318 & 348 & 382 & 382 & 103 & 0 & 0 & 0 & 0 & 0 & 0 & 0 & 0 & 0 & 0 \\
\hline 2.3 & Payment of loan interest & 68 & 136 & 125 & 112 & 98 & 83 & 66 & 48 & 28 & 28 & 6 & 0 & 0 & 0 & 0 & 0 & 0 & 0 & 0 & 0 & 0 \\
\hline 2.4 & Running cost & 0 & 1068 & 1068 & 1068 & 1068 & 1068 & 1068 & 1068 & 1068 & 1068 & 1068 & 1068 & 1068 & 1068 & 1068 & 1068 & 1068 & 1068 & 1068 & 1068 & 1068 \\
\hline 2.5 & VAT and addtion & 0 & 120 & 120 & 120 & 120 & 120 & 120 & 120 & 120 & 120 & 120 & 120 & 120 & 120 & 120 & 120 & 120 & 120 & 120 & 120 & 120 \\
\hline 2.6 & Income tax & 0 & 63 & 67 & 71 & 75 & 80 & 86 & 92 & 98 & 106 & 108 & 108 & 108 & 108 & 108 & 108 & 108 & 108 & 108 & 108 & 108 \\
\hline 3 & Net cash flow: 1-2 & -1083 & 136 & 125 & 112 & 98 & 83 & 66 & 48 & 28 & 21 & 320 & 429 & 429 & 429 & 429 & 429 & 429 & 429 & 429 & 429 & 429 \\
\hline \multirow[t]{4}{*}{4} & Accumulated net cash flow: 1-2 & -1083 & -947 & -822 & -710 & -611 & -528 & -462 & -414 & -386 & $|-365|$ & -46 & 383 & 811 & 1240 & 1668 & 2097 & 2525 & 2954 & 3383 & 3811 & 4240 \\
\hline & IRR $(\%)$ & \multicolumn{21}{|c|}{12.02} \\
\hline & NPV (ic $=10 \%, 10^{4}$ Yuan) & \multicolumn{21}{|c|}{646.9} \\
\hline & Investment payback period (yr.) & \multicolumn{21}{|c|}{10.11} \\
\hline
\end{tabular}


Annex3-1: Total cost

Unit: $10^{4}$ yuan

\begin{tabular}{|c|c|c|c|c|c|c|c|c|c|c|c|c|c|c|c|c|c|}
\hline \multirow{3}{*}{ No } & \multirow{3}{*}{\multicolumn{2}{|c|}{\begin{tabular}{|c|c|}
\multirow{2}{*}{ Item } & $\begin{array}{c}\text { Construction } \\
\text { period }\end{array}$ \\
\cline { 2 - 2 } & 1 \\
\end{tabular}}} & \multirow{2}{*}{\multicolumn{15}{|c|}{ Production period of reaching the designed capacity }} \\
\hline & & & & & & & & & & & & & & & & & \\
\hline & & & 1 & 2 & 3 & 4 & 5 & 6 & 7 & 8 & 9 & 10 & 11 & 12 & 13 & 14 & 15 \\
\hline 1 & Fuel \& power & & 801.8 & 801.8 & 801.8 & 801.8 & 801.8 & 801.8 & 801.8 & 801.8 & 801.8 & 801.8 & 801.8 & 801.8 & 801.8 & 801.8 & 801.8 \\
\hline 2 & Salary \& welfare & & 100.0 & 100.0 & 100.0 & 100.0 & 100.0 & 100.0 & 100.0 & 100.0 & 100.0 & 100.0 & 100.0 & 100.0 & 100.0 & 100.0 & 100.0 \\
\hline 4 & Reparation cost & & 70.0 & 70.0 & 70.0 & 70.0 & 70.0 & 70.0 & 70.0 & 70.0 & 70.0 & 70.0 & 70.0 & 70.0 & 70.0 & 70.0 & 70.0 \\
\hline 5 & Depreciation cost & & 232.8 & 232.8 & 232.8 & 232.8 & 232.8 & 232.8 & 232.8 & 232.8 & 232.8 & 232.8 & 232.8 & 232.8 & 232.8 & 232.8 & 232.8 \\
\hline 6 & Amortizing cost & & 0.0 & 0.0 & 0.0 & 0.0 & 0.0 & 0.0 & 0.0 & 0.0 & 0.0 & 0.0 & 0.0 & 0.0 & 0.0 & 0.0 & 0.0 \\
\hline 7 & Fiscal cost & 75.6 & 151.2 & 141.1 & 130.1 & 118.1 & 104.9 & 90.5 & 74.8 & 57.7 & 38.9 & 18.4 & 0.0 & 0.0 & 0.0 & 0.0 & 0.0 \\
\hline 7.1 & $\begin{array}{l}\text { Long-term interest rate } \\
\text { of loan }\end{array}$ & 75.6 & 151.2 & 141.1 & 130.1 & 118.1 & 104.9 & 90.5 & 74.8 & 57.7 & 38.9 & 18.4 & 0.0 & 0.0 & 0.0 & 0.0 & 0.0 \\
\hline 7.2 & $\begin{array}{l}\text { Interest of loan of flow } \\
\text { finance }\end{array}$ & & & & & & & & & & & & & & & & \\
\hline \multirow[t]{3}{*}{8} & Total cost $(1+2+\ldots+8)$ & 75.6 & 1355.9 & 1345.8 & 1334.7 & 1322.7 & 1309.5 & 1295.1 & 1279.4 & 1262.3 & 1243.5 & 1223.0 & 1204.6 & 1204.6 & 1204.6 & 1204.6 & 1204.6 \\
\hline & Fixed cost & 0.0 & 402.8 & 402.8 & 402.8 & 402.8 & 402.8 & 402.8 & 402.8 & 402.8 & 402.8 & 402.8 & 402.8 & 402.8 & 402.8 & 402.8 & 402.8 \\
\hline & Variable cost $(1+2+7)$ & 75.6 & 953.1 & 943.0 & 931.9 & 919.9 & 906.7 & 892.3 & 876.6 & 859.5 & 840.7 & 820.3 & 801.8 & 801.8 & 801.8 & 801.8 & 801.8 \\
\hline 9 & Operation cost $(8-5-6-7)$ & 0.0 & 971.8 & 971.8 & 971.8 & 971.8 & 971.8 & 971.8 & 971.8 & 971.8 & 971.8 & 971.8 & 971.8 & 971.8 & 971.8 & 971.8 & 971.8 \\
\hline
\end{tabular}




\begin{tabular}{|c|c|c|c|c|c|c|c|c|c|c|c|c|c|c|c|c|c|}
\hline \multirow[b]{2}{*}{ No } & \multirow[b]{2}{*}{ Item } & \multicolumn{7}{|l|}{ Construction period } & \multicolumn{9}{|c|}{ Operating period } \\
\hline & & 1 & 1 & 2 & 3 & 4 & 5 & 6 & 7 & 8 & 9 & 10 & 11 & 12 & 13 & 14 & 15 \\
\hline 1 & Repaying loan and interest & & & & & & & & & & & & & & & & \\
\hline 1.1 & Accumulative loan and interest in beginning year & 0.0 & 2625.9 & 2450.5 & 52258.9 & 2049.7 & 71821.1 & 1571.5 & 1298.8 & 81000.9 & 675.5 & 320.0 & 0.0 & 0.0 & 0.0 & 0.0 & 0.0 \\
\hline 1.1 .1 & Loan & 0.0 & 2625.9 & 2450.5 & 52258.9 & 2049.7 & 1821.1 & 1571.5 & 1298.8 & 81000.9 & 675.5 & 320.0 & 0.0 & 0.0 & 0.0 & 0.0 & 0.0 \\
\hline 1.1 .2 & Interest of construction period & 75.6 & & & & & & & & & & & & & & & \\
\hline 1.2 & Annual loan & 2625.9 & & & & & & & & & & & & & & & \\
\hline 1.3 & Interest & 75.6 & 151.2 & 141.1 & 130.1 & 118.1 & 104.9 & 90.5 & 74.8 & 57.7 & 38.9 & 18.4 & 0.0 & 0.0 & 0.0 & 0.0 & 0.0 \\
\hline 1.4 & Return loan & 0.0 & 175.4 & 191.6 & 209.2 & 228.6 & 249.7 & 272.7 & 297.9 & 325.4 & 355.4 & 320.0 & 0.0 & 0.0 & 0.0 & 0.0 & 0.0 \\
\hline 1.5 & Return interest & 75.6 & 151.2 & 141.1 & 130.1 & 118.1 & 104.9 & 90.5 & 74.8 & 57.7 & 38.9 & 18.4 & 0.0 & 0.0 & 0.0 & 0.0 & 0.0 \\
\hline 2 & Capital source for repay loan & & 326.6 & 332.7 & 339.4 & 346.6 & 354.6 & 363.2 & 372.7 & 383.1 & 394.4 & 406.7 & 417.8 & 417.8 & 417.8 & 417.8 & 417.8 \\
\hline 2.1 & Profit & & 93.8 & 99.9 & 106.6 & 113.8 & 121.8 & 130.4 & 139.9 & 150.3 & 161.6 & 173.9 & 185.0 & 185.0 & 185.0 & 185.0 & 185.0 \\
\hline 2.2 & Depreciation & & 232.8 & 232.8 & 232.8 & 232.8 & 232.8 & 232.8 & 232.8 & 232.8 & 232.8 & 232.8 & 232.8 & 232.8 & 232.8 & 232.8 & 232.8 \\
\hline
\end{tabular}


Annex3- 3: Profit and loss statement

Unit: $10^{4}$ yuan

\begin{tabular}{|c|c|c|c|c|c|c|c|c|c|c|c|c|c|c|c|c|c|}
\hline & \multirow{3}{*}{ Item } & \multirow{3}{*}{\begin{tabular}{|c|}
$\begin{array}{c}\text { Construction } \\
\text { period }\end{array}$ \\
1 \\
\end{tabular}} & \multirow{2}{*}{\multicolumn{15}{|c|}{ Operation period }} \\
\hline \multirow[b]{2}{*}{ No } & & & & & & & & & & & & & & & & & \\
\hline & & & 1 & 2 & 3 & 4 & 5 & 6 & 7 & 8 & 9 & 10 & 11 & 12 & 13 & 14 & 15 \\
\hline 1 & Product turnover & & 1646.5 & 1646.5 & 1646.5 & 1646.5 & 1646.5 & 1646.5 & 1646.5 & 1646.5 & 1646.5 & 1646.5 & 1646.5 & 1646.5 & 1646.5 & 1646.5 & 1646.5 \\
\hline 2 & $\begin{array}{|lll|}\begin{array}{l}\text { Turnover tax } \\
\text { add-ons }\end{array} & \text { and } \\
\end{array}$ & & 135.0 & 135.0 & 135.0 & 135.0 & 135.0 & 135.0 & 135.0 & 135.0 & 135.0 & 135.0 & 135.0 & 135.0 & 135.0 & 135.0 & 135.0 \\
\hline 3 & Total cost & 75.62 & 1355.9 & 1345.8 & 1334.7 & 1322.7 & 1309.5 & 1295.1 & 1279.4 & 1262.3 & 1243.5 & 1223.0 & 1204.6 & 1204.6 & 1204.6 & 1204.6 & 1204.6 \\
\hline 4 & Total profit: $1-2-3$ & & 155.6 & 165.7 & 176.7 & 188.8 & 201.9 & 216.3 & 232.0 & 249.2 & 267.9 & 288.4 & 306.8 & 306.8 & 306.8 & 306.8 & 306.8 \\
\hline 5 & Income tax $(33 \%)$ & & 51.3 & 54.7 & 58.3 & 62.3 & 66.6 & 71.4 & 76.6 & 82.2 & 88.4 & 95.2 & 101.3 & 101.3 & 101.3 & 101.3 & 101.3 \\
\hline 6 & Profit after tax: $4-5$ & & 104.2 & 111.0 & 118.4 & 126.5 & 135.3 & 144.9 & 155.5 & 167.0 & 179.5 & 193.2 & 205.6 & 205.6 & 205.6 & 205.6 & 205.6 \\
\hline 8 & $\begin{array}{l}\text { Profit can be allocated: } \\
6-7\end{array}$ & & 104.2 & 111.0 & 118.4 & 126.5 & 135.3 & 144.9 & 155.5 & 167.0 & 179.5 & 193.2 & 205.6 & 205.6 & 205.6 & 205.6 & 205.6 \\
\hline 9 & $\begin{array}{l}\text { Surplus accumulating } \\
\text { fund }(10 \%)\end{array}$ & & 10.4 & 11.1 & 11.8 & 12.6 & 13.5 & 14.5 & 15.5 & 16.7 & 18.0 & 19.3 & 20.6 & 20.6 & 20.6 & 20.6 & 20.6 \\
\hline 10 & Profit to be paid & & & & & & & & & & & & & & & & \\
\hline 11 & $\begin{array}{|ll|}\begin{array}{l}\text { Profit not being } \\
\text { distributed }\end{array} & \\
\end{array}$ & & 93.8 & 99.9 & 106.6 & 113.8 & 121.8 & 130.4 & 139.9 & 150.3 & 161.6 & 173.9 & 185.0 & 185.0 & 185.0 & 185.0 & 185.0 \\
\hline & $\begin{array}{l}\text { Accumulated profit not } \\
\text { being distributed }\end{array}$ & & 93.8 & 193.7 & 300.3 & 414.1 & 535.9 & 666.4 & 806.3 & 956.5 & 1118.1 & 1292.0 & 1477.0 & 1662.1 & 1847.1 & 2032.1 & 2217.1 \\
\hline
\end{tabular}


Annex 3-4: Cash flow（total capital）

Unit: $10^{4}$ Yuan

\begin{tabular}{|c|c|c|c|c|c|c|c|c|c|c|c|c|c|c|c|c|}
\hline \multirow[b]{2}{*}{ No } & \multirow[b]{2}{*}{ Item } & \multirow{2}{*}{\begin{tabular}{|c|}
$\begin{array}{c}\text { Constructio } \\
\text { n period }\end{array}$ \\
1 \\
\end{tabular}} & \multicolumn{14}{|c|}{ Operation period } \\
\hline & & & 1 & 2 & 3 & 4 & 5 & 6 & 7 & 8 & 9 & 10 & 11 & 12 & 13 & 14 \\
\hline 1 & Cash flow-in & 0 & 1646 & 1646 & 1646 & 1646 & 1646 & 1646 & 1646 & 1646 & 1646 & 1646 & 1646 & 1646 & 1646 & 1646 \\
\hline 1.1 & Product turnover & & 1646 & 1646 & 1646 & 1646 & 1646 & 1646 & 1646 & 1646 & 1646 & 1646 & 1646 & 1646 & 1646 & 1646 \\
\hline 2 & Cash flow -out & 3751 & 1309 & 1303 & 1295 & 1287 & 1278 & 1269 & 1258 & 1247 & 1234 & 1220 & 1208 & 1208 & 1208 & 1208 \\
\hline 2.1 & Fixed assets investment & 3751 & 151 & 141 & 130 & 118 & 105 & 91 & 75 & 58 & 39 & 18 & 0 & 0 & 0 & 0 \\
\hline 2.2 & Flow finance & & & & & & & & & & & & & & & \\
\hline 2.3 & Turnover tax & & 135 & 135 & 135 & 135 & 135 & 135 & 135 & 135 & 135 & 135 & 135 & 135 & 135 & 135 \\
\hline 2.4 & Operational cost & & 972 & 972 & 972 & 972 & 972 & 972 & 972 & 972 & 972 & 972 & 972 & 972 & 972 & 972 \\
\hline 2.5 & Income tax & 0 & 51 & 55 & 58 & 62 & 67 & 71 & 77 & 82 & 88 & 95 & 101 & 101 & 101 & 101 \\
\hline 3 & Net cash flow & -3751 & 337 & 344 & 351 & 359 & 368 & 378 & 388 & 400 & 412 & 426 & 438 & 438 & 438 & 438 \\
\hline \multirow[t]{7}{*}{4} & Accumulated net cash flow & -3751 & -3414 & -3070 & -2719 & -2360 & -1992 & -1614 & -1226 & -826 & -414 & 12 & 451 & 889 & 1327 & 1766 \\
\hline & Net cash flow before tax & -3751 & 388 & 398 & 410 & 422 & 435 & 449 & 465 & 482 & 501 & 521 & 540 & 540 & 540 & 540 \\
\hline & $\begin{array}{l}\text { Accumulated net cash flow } \\
\text { before tax }\end{array}$ & -3751 & -3363 & -2964 & -2555 & -2133 & -1699 & -1249 & -785 & -303 & 198 & 719 & 1259 & 1799 & 2338 & 2878 \\
\hline & Iindex & \multicolumn{8}{|c|}{ After tax } & \multicolumn{7}{|c|}{ Before tax } \\
\hline & FIRR & \multicolumn{8}{|c|}{$6.06 \%$} & \multicolumn{7}{|c|}{$8.74 \%$} \\
\hline & \begin{tabular}{|llll}
$\begin{array}{l}\text { FNPV } \\
\text { yuan })\end{array}$ & Ic $=10 \%($ & Unit: & $10^{4}$ \\
\end{tabular} & \multicolumn{8}{|c|}{15} & \multicolumn{7}{|c|}{714} \\
\hline & Investment return period (year) & \multicolumn{8}{|c|}{11.00} & \multicolumn{7}{|c|}{9.63} \\
\hline
\end{tabular}


Annex 3-5: Cash flow （capital fund )

Unit: $10^{4}$ yuan

\begin{tabular}{|c|c|c|c|c|c|c|c|c|c|c|c|c|c|c|c|c|c|}
\hline \multirow{2}{*}{\multicolumn{2}{|c|}{ NoItem }} & \multirow{2}{*}{$\begin{array}{c}\begin{array}{c}\text { Construction } \\
\text { period }\end{array} \\
1 \\
\end{array}$} & \multicolumn{15}{|c|}{ Operation period } \\
\hline & & & 1 & 2 & 3 & 4 & 5 & 6 & 7 & 8 & 9 & \multirow{2}{*}{\begin{tabular}{|c|}
10 \\
1646.5 \\
\end{tabular}} & \multirow{2}{*}{\begin{tabular}{|c|}
11 \\
1646.5 \\
\end{tabular}} & \multirow{2}{*}{\begin{tabular}{|c|}
12 \\
1646.5
\end{tabular}} & \multirow{2}{*}{\begin{tabular}{|c|}
13 \\
1646.5 \\
\end{tabular}} & \multirow{2}{*}{$\begin{array}{c}14 \\
1646.5 \\
\end{array}$} & \multirow{2}{*}{\begin{tabular}{|c|}
15 \\
1646.5 \\
\end{tabular}} \\
\hline 1 & Cash flow-in & & 1646.5 & 1646.5 & 1646.5 & 1646.5 & 1646.5 & 1646.5 & 1646.5 & 1646.5 & 1646.5 & & & & & & \\
\hline 1. & 1 Turnover & & 1646.5 & 1646.5 & 1646.5 & 1646.5 & 1646.5 & 1646.5 & 1646.5 & 1646.5 & 1646.5 & 1646.5 & 1646.5 & 1646.5 & 1646.5 & 1646.5 & 1646.5 \\
\hline & $\begin{array}{l}\text { Remain value of fixed assets } \\
\text { callback }\end{array}$ & & & & & & & & & & & & & & & & \\
\hline \multicolumn{18}{|c|}{ 1.3 Flow finance callback } \\
\hline 2 & Cash flow-out & 1201.0 & 1484.8 & 1494.2 & 1504.5 & 1515.7 & 1528.0 & 1541.4 & 1556.1 & 1572.1 & 1589.6 & 1540.5 & 1208.1 & 1208.1 & 1208.1 & 1208.1 & 1208.1 \\
\hline & 1 Self-raising finance & 1125.4 & 0.0 & & & & & & & & & & & & & & \\
\hline 2. & 2 Payback loan principal \& interest & 0.0 & 175.4 & 191.6 & 209.2 & 228.6 & 249.7 & 272.7 & 297.9 & 325.4 & 355.4 & 320.0 & 0.0 & 0.0 & 0.0 & 0.0 & 0.0 \\
\hline 2. & 3 Pay interest of loan & 75.6 & 151.2 & 141.1 & 130.1 & 118.1 & 104.9 & 90.5 & 74.8 & 57.7 & 38.9 & 18.4 & 0.0 & 0.0 & 0.0 & 0.0 & 0.0 \\
\hline 2. & 4 Operational cost & 0.0 & 971.8 & 971.8 & 971.8 & 971.8 & 971.8 & 971.8 & 971.8 & 971.8 & 971.8 & 971.8 & 971.8 & 971.8 & 971.8 & 971.8 & 971.8 \\
\hline 2. & 5) Vendition tax \& add-ons & 0.0 & 135.0 & 135.0 & 135.0 & 135.0 & 135.0 & 135.0 & 135.0 & 135.0 & 135.0 & 135.0 & 135.0 & 135.0 & 135.0 & 135.0 & 135.0 \\
\hline & 6 Income tax & 0.0 & 51.3 & 54.7 & 58.3 & 62.3 & 66.6 & 71.4 & 76.6 & 82.2 & 88.4 & 95.2 & 101.3 & 101.3 & 101.3 & 101.3 & 101.3 \\
\hline 3 & Net cash flow: 1-2 & -1201.0 & 161.7 & 152.3 & 142.0 & 130.7 & 118.4 & 105.0 & 90.4 & 74.3 & 56.9 & 106.0 & 438.4 & 438.4 & 438.4 & 438.4 & 438.4 \\
\hline 4 & Accumulated net cash flow & -1201.0 & -1039.3 & -887.1 & -745.1 & $\mid-614.4$ & -496.0 & -391.0 & -300.6 & -226.3 & -169.4 & -63.4 & 375.0 & 813.3 & 1251.7 & 1690.1 & 2128.5 \\
\hline \multicolumn{10}{|c|}{ Iindex } & & & & & & & & \\
\hline & FIRR & \multicolumn{8}{|c|}{$12.04 \%$} & & & & & & & & \\
\hline & FNPV Ic $=10 \%$ ( Unit: $10^{4}$ yuan) & \multicolumn{8}{|c|}{170.24} & & & & & & & & \\
\hline & Investment return period (year) & \multicolumn{8}{|c|}{11.14} & & & & & & & & \\
\hline
\end{tabular}




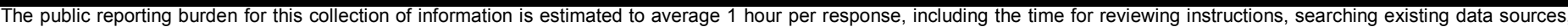

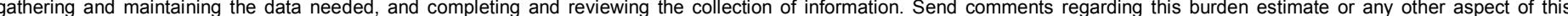

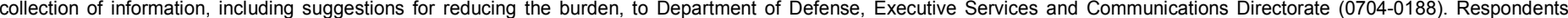

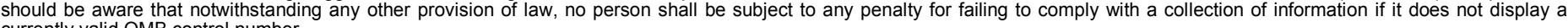
currently valid OMB control number.

PLEASE DO NOT RETURN YOUR FORM TO THE ABOVE ORGANIZATION.

\section{REPORT DATE (DD-MM-YYYY) October 2006 \\ 2. REPORT TYPE \\ Subcontract Report}

4. TITLE AND SUBTITLE

Biomass Support for the China Renewable Energy Law:

Feasibility Report - Agricultural and Forestry Solid Wastes Power

Generation Demonstration, December 2005
3. DATES COVERED (From - To)

5a. CONTRACT NUMBER

DE-AC36-99-GO10337

5b. GRANT NUMBER

5c. PROGRAM ELEMENT NUMBER

5d. PROJECT NUMBER

NREL/SR-710-40627

5e. TASK NUMBER

IGIN.6031

5f. WORK UNIT NUMBER

7. PERFORMING ORGANIZATION NAME(S) AND ADDRESS(ES)

Center of Renewable Energy Development, Beijing, China; Energy

Research Institute, Beijing, China; National Development and Reform REPORT NUMBER

Commission, Beijing, China

ACO-4-44015-01

9. SPONSORING/MONITORING AGENCY NAME(S) AND ADDRESS(ES)

National Renewable Energy Laboratory

1617 Cole Blvd.

Golden, CO 80401-3393

10. SPONSOR/MONITOR'S ACRONYM(S) NREL

11. SPONSORING/MONITORING AGENCY REPORT NUMBER NREL/SR-710-40627

12. DISTRIBUTION AVAILABILITY STATEMENT

National Technical Information Service

U.S. Department of Commerce

5285 Port Royal Road

Springfield, VA 22161

13. SUPPLEMENTARY NOTES

NREL Technical Monitor: Debra Lew

14. ABSTRACT (Maximum 200 Words)

Subcontractor report on feasibility of using agricultural and forestry wastes for power generation in China.

15. SUBJECT TERMS

International Programs; China; Biomass; agricultural waste; forestry waste; China Renewable Energy Law; biomass development in China

16. SECURITY CLASSIFICATION OF:
\begin{tabular}{l|l|l|}
\hline $\begin{array}{l}\text { a. REPORT } \\
\text { Unclassified }\end{array}$ & $\begin{array}{l}\text { b. ABSTRACT } \\
\text { Unclassified }\end{array}$ & Unclassified \\
\end{tabular}

\begin{tabular}{|c|c|}
\hline $\begin{array}{l}\text { 17. LIMITATION } \\
\text { OF ABSTRACT }\end{array}$ & $\begin{array}{l}\text { 18. NUMBER } \\
\text { OF PAGES }\end{array}$ \\
\hline UL & \\
\hline
\end{tabular}

19a. NAME OF RESPONSIBLE PERSON

19b. TELEPONE NUMBER (Include area code) 